\title{
A multi-proxy record of the Latest Danian Event at Gebel Qreiya, Eastern Desert, Egypt
}

\author{
J. SPRONG ${ }^{1}$, M. A. YOUSSEF ${ }^{2}$, A. BORNEMANN ${ }^{3}$, P. SCHULTE ${ }^{4}$, E. STEURBAUT ${ }^{1,5}$, P. STASSEN ${ }^{1}$, \\ T. J. KOUWENHOVEN ${ }^{1, *} \&$ R. P. SPEIJER ${ }^{1}$ \\ ${ }^{1}$ Department of Earth and Environmental Sciences, K.U. Leuven, Celestijnenlaan 200E, B-3001 Heverlee, Belgium \\ ${ }^{2}$ Geology Department, Faculty of Science, South Valley University, 83523 Qena, Egypt \\ ${ }^{3}$ Institute of Geophysics and Geology, Leipzig University, Talstraße 35, 04103 Leipzig, Germany \\ ${ }^{4}$ GeoZentrum Nordbayern, Universität Erlangen, Schloßgarten 5, 91054 Erlangen, Germany \\ ${ }^{5}$ Royal Belgian Institute of Natural Sciences, Vautierstraat 29, B-1000 Brussels, Belgium \\ ${ }^{*}$ Corresponding author (e-mail: Tanja.Kouwenhoven@ees.kuleuven.be)
}

\begin{abstract}
The Latest Danian Event (LDE) is a proposed early Palaeogene transient warming event similar to the Paleocene-Eocene Thermal Maximum, albeit of smaller magnitude. The LDE can be correlated with a carbon isotope excursion ('CIE-DS1') at Zumaia, Spain, and the 'top Chron C27n event' defined recently from ocean drilling sites in the Atlantic and Pacific, supporting a global extent. Yet, records of environmental change during the LDE (e.g. warming and sea-level fluctuations) are still rare. In this study, we focus on the micropalaeontology (calcareous nannofossils and benthic foraminifera), mineralogy and trace element geochemistry of the LDE in the Qreiya 3 section from the southern Tethyan margin in Egypt. In this section, the LDE is characterized by the occurrence of anomalous beds intercalated within upper Danian shales and marls. The event beds of the LDE are situated above an unconformity on top of a shallowing-upwards sequence deposited in a well-oxygenated outer neritic to upper bathyal marine palaeoenvironment. The lower LDE bed is barren of benthic foraminifera, but contains pyrite and fish remains, and is interpreted as an anoxic level formed during rapid relative sea-level rise. Incursion of a Neoeponides duwi (Nakkady, 1950) benthic assemblage in LDE bed II is interpreted as repopulation of the seafloor after anoxia. The sea-level cycle associated with the LDE is estimated at about $50 \mathrm{~m}$ maximum in the Qreiya 3 section. The environmental changes at Qreiya 3 are of supraregional extent, since a similar sequence of events has been observed at other southern Tethyan locations. J. Micropalaeontol. 30(2): 167-182, September 2011.
\end{abstract}

Supplementary material: A table of floral, faunal and geochemical data is available at: http://www.geolsoc.org.uk/SUP18497

KEYWORDS: Tethyan margin, Latest Danian Event, benthic foraminifera, calcareous nannofossils, trace element geochemistry

\section{INTRODUCTION}

Recent studies provide strong evidence that several transient warming events have preceded and followed the PaleoceneEocene Thermal Maximum (PETM; e.g. Speijer, 2000, 2003a; Thomas \& Zachos, 2000; Lourens et al., 2005; Petrizzo, 2005; Bernaola et al., 2007; Nicolo et al., 2007; Quillévéré et al., 2008; Agnini et al., 2009; Stap et al., 2009; Coccioni et al., 2010). One of the proposed Paleocene hyperthermals is the Latest Danian Event (LDE), described from sections located at the southern Tethyan margin in Egypt (Sprong, pers.com.; Bornemann et al., 2009; Sprong et al., 2009; Youssef, 2009; 'el-Qreiya event' in Soliman \& Obaidalla, 2010). Although it has been suspected that the LDE might reflect a hyperthermal (e.g. Speijer, 2000, 2003a; Bornemann et al., 2009; Youssef, 2009), a reliable high-resolution stable oxygen isotope record, necessary to prove warming, is difficult to obtain in the sediments from Egypt (Bornemann et al., 2009). In addition, the LDE has been associated with the Danian-Selandian transition because the stratigraphical position of the southern Tethyan LDE beds was not well enough constrained for correlation with other records (e.g. Speijer, 2003a; Guasti, unpublished thesis, University of Bremen, 2005; Soliman \& Obaidalla, 2010). Since the DanianSelandian boundary has been formally defined in the Zumaia section in Spain (Schmitz et al., 2008), and the biostratigraphical resolution of this interval has been refined (Agnini et al., 2007;
Arenillas et al., 2008; Bernaola et al., 2009; Sprong et al., 2009), the LDE in Egypt and its correlative level in Tunisia (e.g. Steurbaut et al., 2000; Guasti et al., 2006; Van Itterbeeck et al., 2007) is found to be time-equivalent with the 'top Chron C27n event' in open ocean records (Westerhold et al., 2008, 2011) and with the 'CIE-DS1' event in Zumaia (Arenillas et al., 2008; Dinarès-Turell et al., 2010). Thus, the LDE as described from Egypt most probably represents one of the proposed Paleocene hyperthermals preceding the PETM.

The LDE is characterized by a $1-2 \%$ oxcursion towards lighter $\delta^{13} \mathrm{C}$ values (Bornemann et al., 2009; Westerhold et al., 2011). The LDE beds at Gebel Qreiya correlate with other sections in the Nile Basin showing a set of event beds and the incursion of the benthic foraminifer Neoeponides duwi (Speijer \& Schmitz, 1998; Speijer, 2000, 2003a, b). At the Qreiya 3 section, located near the southern peak of the Gebel Qreiya plateau (Fig. 1 ), the LDE is expressed as a $25 \mathrm{~cm}$ thick couplet consisting of a dark purplish-brown marl bed overlain by a dark grey shale bed, intercalated in the brown-grey upper Danian Dakhla shales. The basal LDE bed I is rich in organic carbon and fish remains, barren of benthic foraminifera and shows unusual, low-diversity planktic foraminiferal assemblages, strongly dominated by non-keeled, muricate and praemuricate taxa. The upper LDE bed II is dominated by $N$. duwi in association with shallow-water benthic foraminifera (Speijer, 2000, 2003a). The 


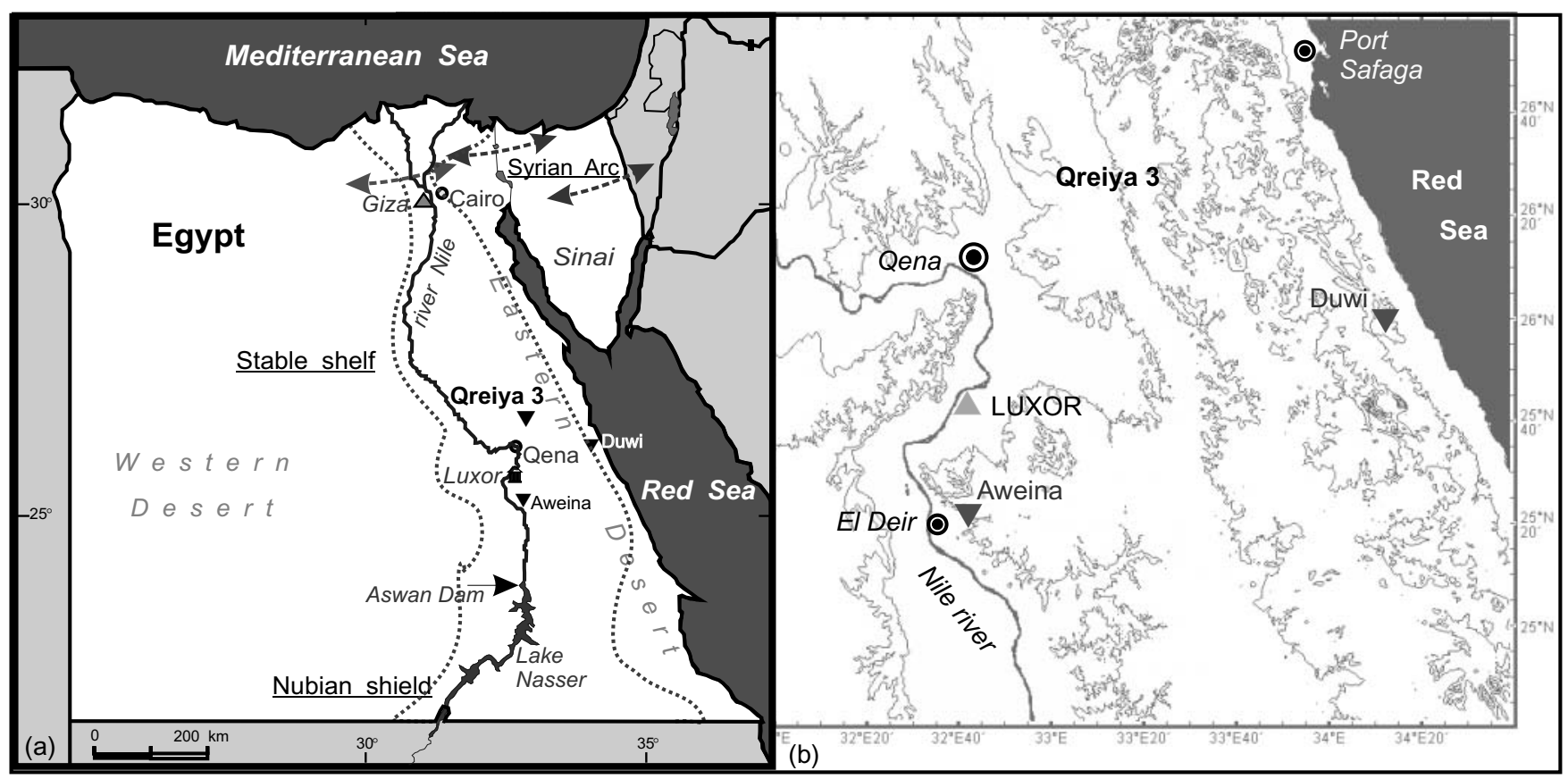

Fig. 1. Location map: (a) overview; (b) detailed map. Gebel Qreiya is located north of the town of Qena, near the southern entrance of Wadi Qena. For coordinates of the Qreiya 3 section, see text. Also indicated are the Duwi and Aweina sections. Dotted line: approximate outline of the Nile Basin. Double arrows: Syrian Arc (unstable shelf).

LDE beds at Gebel Qreiya resemble the organic-rich dark brown layers at the PETM in the Esna Shale Formation (Speijer, 2000, 2003a; Knox et al., 2003), but no extinction of benthic foraminifera is observed during the LDE (e.g. Speijer, 2003a).

In this paper we present a high-resolution multi-proxy study of the LDE at the Qreiya 3 section. Benthic foraminifera, mineralogy and trace element geochemistry are used to reconstruct changes in the palaeoenvironment, and to constrain relative sea-level fluctuations across the LDE.

\section{GEOLOGICAL BACKGROUND}

Location and geological setting

Gebel Qreiya is situated east of the southern entrance of Wadi Qena in the Eastern Desert, Egypt (Fig. 1). Wadi Qena is a $\sim 300 \mathrm{~km}$ long valley, extending from the slopes of the Galala mountains in the north to the town of Qena in the south, where it opens into the Nile Valley. Paleocene to lower Eocene marl-shale successions are well exposed at Gebel Qreiya. Section Qreiya $3\left(26^{\circ} \mathrm{N} 27^{\prime} 42^{\prime \prime}\right.$ and $\left.33^{\circ} \mathrm{E} 1^{\prime} 54^{\prime \prime}\right)$ is situated near the southern tip of Gebel Qreiya, about $50 \mathrm{~km}$ northeast of the town of Qena, north of the road from Qena to Safaga.

During Danian-Selandian times ( 65-59 Ma; Luterbacher et al., 2004), the southern margin of the Nile Basin was situated close to the present southern border of Egypt (Luger, 1988). The basin was characterized by neritic to upper bathyal marl and shale deposition of the Dakhla Formation (Fm.) in a basin generally deepening to the northwest (Speijer, 2003a and references therein). Micropalaeontological data indicate Danian and Selandian palaeodepths ranging from $70-150 \mathrm{~m}$ at Gebel Duwi, near the Red Sea coast, to $400-600 \mathrm{~m}$ in Sinai. Deposition at
Gebel Qreiya took place at outer neritic to upper bathyal palaeodepths (150-250 m; Speijer, 2003a).

\section{Lithology}

The Paleocene succession of Gebel Qreiya consists of the upper part of the Dakhla, the Tarawan and the lower part of the Esna formations (Said, 1962; Hendriks et al., 1987). We studied $16.5 \mathrm{~m}$ of the upper part of the Dakhla Fm. (Fig. 2a, b). The Qreiya 3 section is a composite of two subsections (Fig. 2a). Upper subsection B, starting at the base of LDE bed I, is located $10 \mathrm{~m}$ to the northeast of lower subsection $\mathrm{A}$. The interval between $8.05 \mathrm{~m}$ and $8.20 \mathrm{~m}$ consists of dark grey carbonate-poor shale of the Dakhla Fm., containing mm- to cm-sized burrows at the top. At $8.20 \mathrm{~m}$, the LDE beds are intercalated within the Dakhla shales. The lithological transition is abrupt, is not bioturbated and contains (secondary) gypsum.

The LDE beds I and II are characterized as follows:

- Bed I (8.20-8.30 m) consists of dark purplish-brown laminated marl, rich in organic matter. It contains abundant fish remains (including fish imprints with partial scale preservation: Fig. 3), pyritized moulds of planktic foraminifera, and some coprolites. In situ benthic foraminifera are not present. The upper $7 \mathrm{~cm}$ of bed I contain dark grey clay lenses: these are burrows penetrating downwards from bed II containing benthic foraminifera. The sample at $8.29 \mathrm{~m}$ is very rich in planktic foraminifera.

- Bed II (8.30-8.45 m) consists of grey to dark grey shale, rich in organic matter. This bed contains planktic and benthic foraminifera, and pyritized moulds of bivalves and gastropods. Between $8.42 \mathrm{~m}$ and $8.45 \mathrm{~m}$ the sediment consists of 
The Latest Danian Event at Gebel Qreiya, Eastern Desert, Egypt
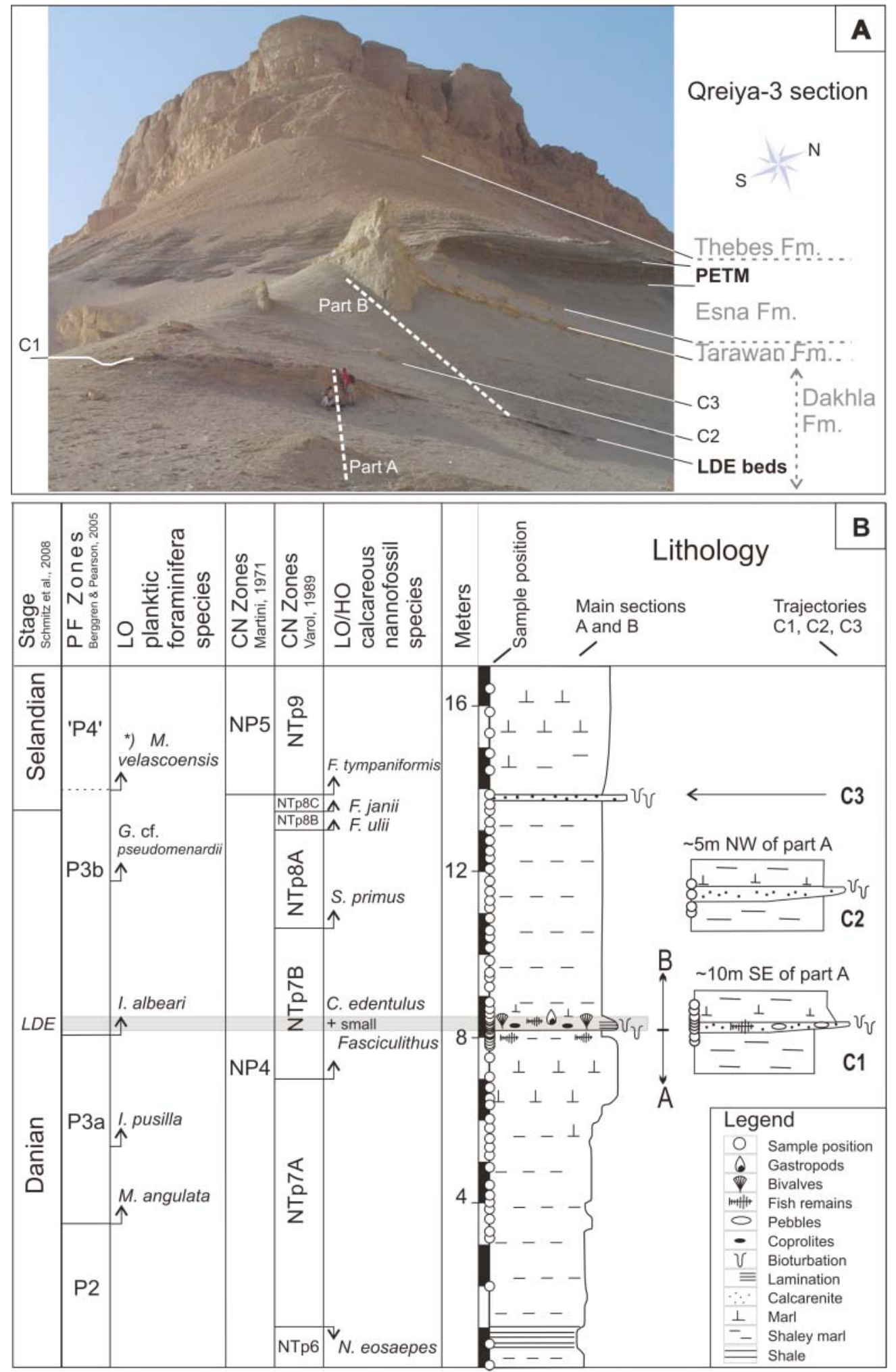

Fig. 2. Lithology and biostratigraphy of the Qreiya 3 section. (A) Photograph of the section showing the Dakhla, Tarawan, Esna and Thebes formations. The section was sampled in the Dakhla shales in two subsections A and B. The calcarenitic beds C1-C3, the Latest Danian Event beds (LDE) and the PETM are indicated. (B) Schematic lithology and biostratigraphical datums. Calcareous nannoplankton zonation follows Martini (1971) and Varol (1989); planktic foraminiferal biozonation follows Berggren \& Pearson (2005). LDE, position of LDE beds I and II (grey shaded interval). Asterisk, LO of M. velascoensis was used to approximate the base of Zone P4, which is for this reason denoted as 'P4'; see text for explanation. 


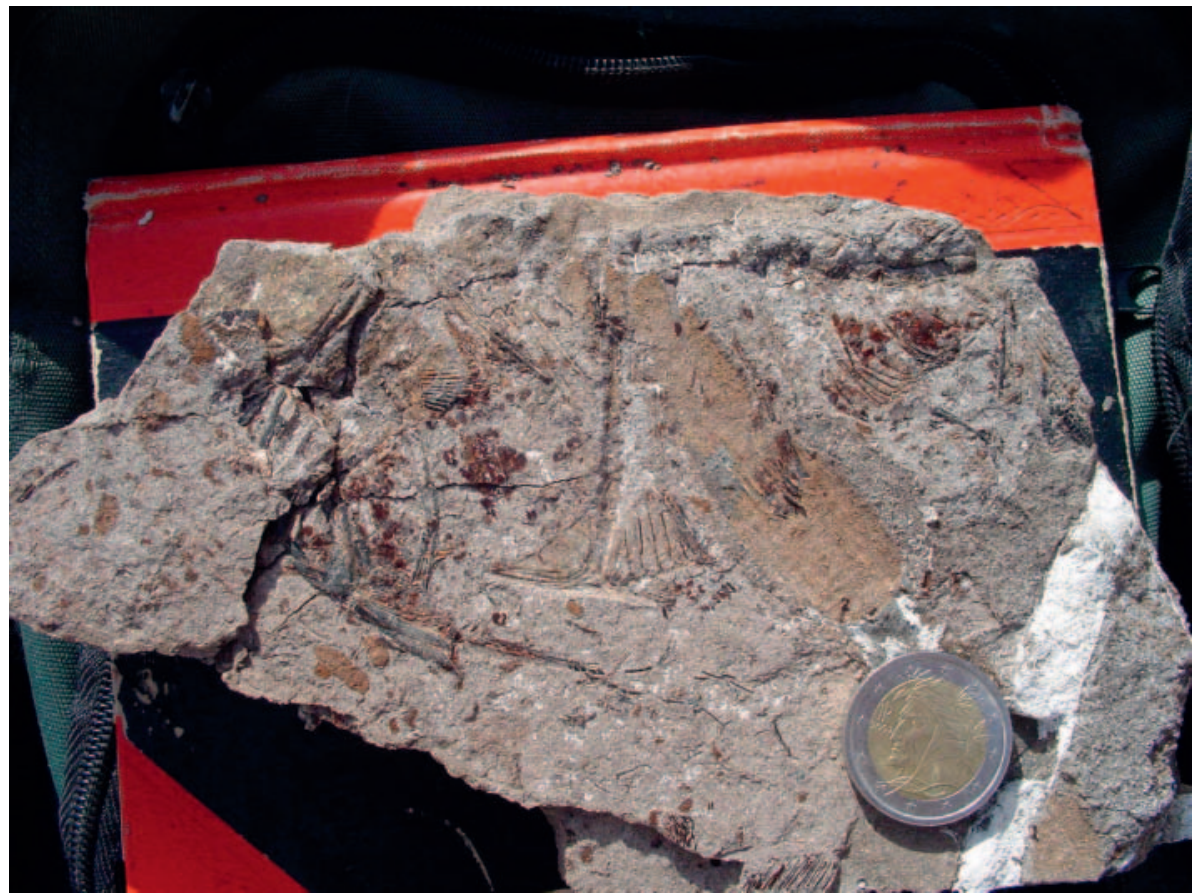

Fig. 3. Fish imprints and partially preserved fish scales, LDE bed I. Scale is a $€ 2$ coin.

purplish-brown marl and grey marly shale with laminae, flaser bedding and abundant pyritized moulds of planktic foraminifera.

Ten metres south of the main Qreiya subsection A, a several metres wide and up to $15 \mathrm{~cm}$ thick, lens-shaped calcarenitic bed cuts through the LDE beds (Fig. 2). This yellowish-grey upwards-fining bed $(\mathrm{C} 1)$ rests on top of a $1 \mathrm{~cm}$ thick sand layer; it contains clay pebbles at the base, fish remains, and the upper surface is heavily bioturbated. A second lens-shaped calcarenitic bed (C2), about $30 \mathrm{~cm}$ thick and $10 \mathrm{~m}$ wide, is intercalated above the LDE beds at $11.4 \mathrm{~m}$. Further up-section, at $13.8 \mathrm{~m}$, a third calcarenitic bed (C3), about $50 \mathrm{~m}$ wide and up to $20 \mathrm{~cm}$ thick, is intercalated in the Dakhla shales. Both the bottom and top of this calcarenitic bed are heavily bioturbated. The calcarenite beds $\mathrm{C} 1-\mathrm{C} 3$ are interpreted as channel fills, incising the normal sedimentary succession.

\section{METHODS}

Samples were collected from $10-30 \mathrm{~cm}$ deep trenches or holes along the outcrop to obtain fresh sediment. Sample spacing was generally $25 \mathrm{~cm}$; the interval comprising the LDE was sampled every $2-5 \mathrm{~cm}$.

\section{Foraminifera}

For analysis of benthic foraminifera, 78 samples were selected: 59 from the main section and 19 from calcarenites C1-C3 (see Supplementary Material). The samples were dried at $60^{\circ} \mathrm{C}$ for 24 hours, weighed, disintegrated in a soda solution $\left(50 \mathrm{~g}^{-1}\right.$ $\mathrm{Na}_{2} \mathrm{CO}_{3}$ ) and washed over a set of $2 \mathrm{~mm}$ and $63 \mu \mathrm{m}$ sieves. The residues were dry-sieved over $630 \mu \mathrm{m}$ and $125 \mu \mathrm{m}$ sieves. Benthic foraminifer counts were obtained from the fraction $125-630 \mu \mathrm{m}$ (see Supplementary Material). Representative aliquots containing 200-300 specimens were obtained with an ASC microsplitter. Foraminifera were picked from the washed residues, transferred to micropalaeontological slides and stored at the Department of Earth and Environmental Sciences, K.U. Leuven (Belgium) for future reference. Relative abundances were calculated, and absolute numbers of planktic and benthic foraminifera (PFN, BFN: planktic and benthic foraminiferal numbers per gram of dry sediment; Fig. 4 and Supplementary Material). Benthic diversity (Shannon index S[H]: Shannon \& Weaver, 1949) and dominance (Simpson index: Hammer et al., 2001) were determined. The $\mathrm{P} / \mathrm{B}$ ratio, derived from counting random squares in the picking tray, is expressed as $100 \times \mathrm{P} /(\mathrm{P}+\mathrm{B})$ and was used as a first estimate of relative palaeodepth (e.g. Grimsdale \& Van Morkhoven, 1955; Berger \& Diester-Haass, 1988; Van der Zwaan et al., 1990). In addition, water-depth preferences were assigned to species on the basis of literature data from Egypt and Tunisia (Fig. 5). The terms 'neritic' and 'bathyal' are commonly used to discriminate between palaeodepths less than, and in excess of $200 \mathrm{~m}$ (e.g. Van Morkhoven et al., 1986). Here, we use the terms inner neritic (IN), middle neritic $(\mathrm{MN})$, outer neritic $(\mathrm{ON})$ and bathyal $(\mathrm{B})$ for palaeodepths of $<50 \mathrm{~m}, 50-100 \mathrm{~m}, 100-200 \mathrm{~m}$ and $>200 \mathrm{~m}$, respectively.

For correspondence analysis (CA) the samples from the calcarenitic levels $\mathrm{C} 1-\mathrm{C} 3$, interpreted as channel fills, were excluded. PAST computer software (Hammer et al., 2001) was used to run CA on the relative abundance data. The barren sample at $8.2 \mathrm{~m}$ was omitted from the analyses; however, the sample at $8.25 \mathrm{~m}$ containing downwards bioturbated benthic foraminifera was included. Only taxa occurring in relative frequencies $>2 \%$ in any sample were retained in the analysis. Correspondence analysis was run on 58 samples and 53 taxa. 


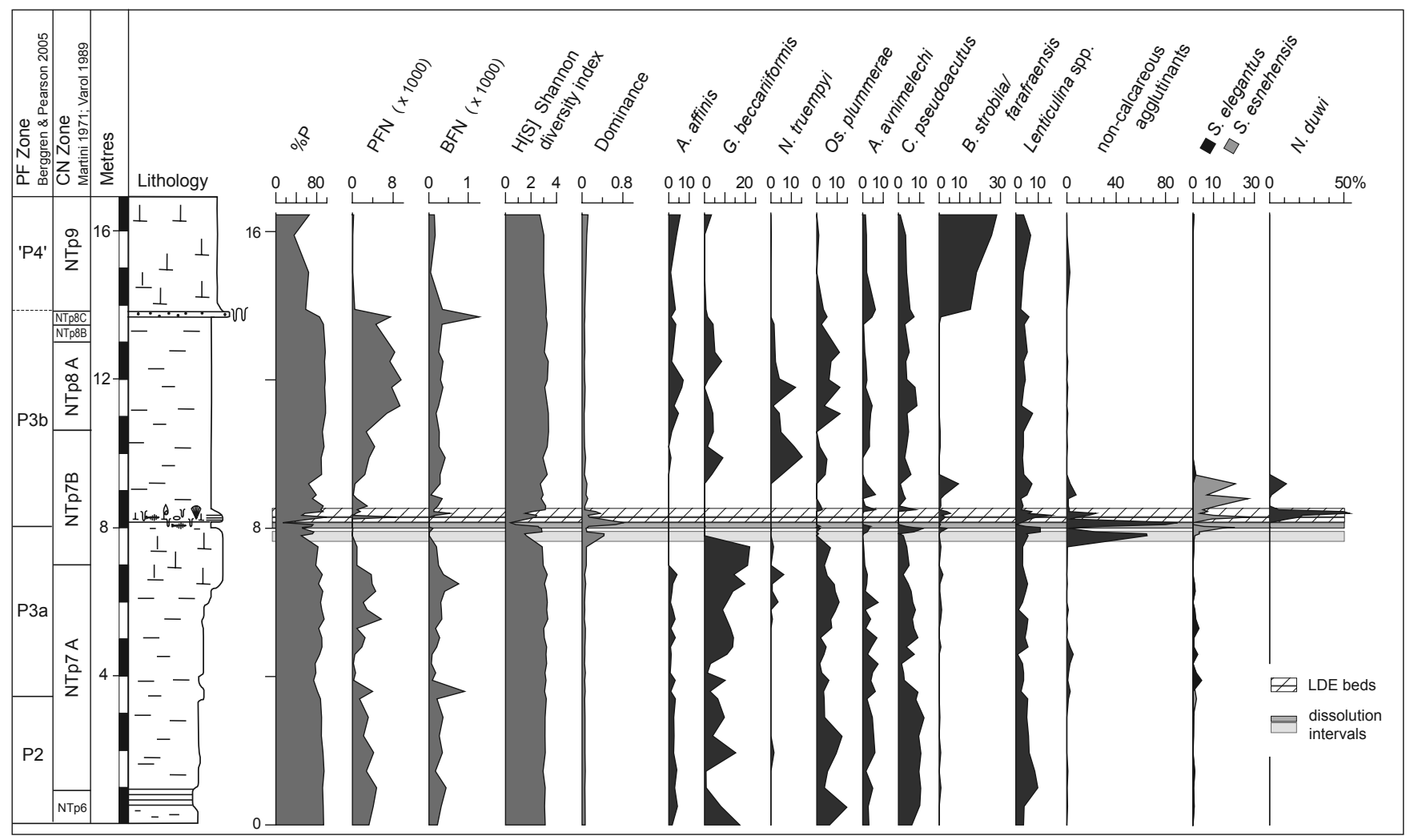

Fig. 4. Foraminifera data. Calcarenitic levels $\mathrm{C} 1-\mathrm{C} 3$ not included. Left panel: $\mathrm{P} / \mathrm{B}$ ratio expressed as \% $\mathrm{P}$; planktic foraminifera per gram of dry sediment (PFN); benthic foraminifera per gram of dry sediment (BFN), Shannon index H[S] for benthic foraminifer diversity, Simpson index for dominance in benthic foraminifer associations. Right panel: relative frequencies of selected benthic foraminifer taxa. Hatched bars indicate Latest Danian Event beds (LDE, bed $\mathrm{I}=8.2-8.3 \mathrm{~m}$ and bed $\mathrm{II}=8.3-8.45 \mathrm{~m})$; grey bars indicate dissolution levels below LDE $(7.85-8$ and $8.05-8.2 \mathrm{~m})$.

\section{Calcareous nannofossils}

Calcareous nannofossil biostratigraphy was determined from standard smear-slides following Martini (1971) and Varol (1989). Calcarenitic levels C1-C3 were excluded. Nannofossils were qualitatively analysed in 76 samples, using standard procedures as described in Perch-Nielsen (1985). Smear slides were examined with a light microscope at $1000 \times$ magnification. At least three traverses of each slide ( 600 fields of view) were searched for zonal markers. Random settling slides, as described in Geisen et al. (1999), were used for a quantitative nannofossil investigation on the 76 samples (see Supplementary Material). In each slide, 300 individuals (or max. 200 fields of view) were identified and counted. Relative and absolute abundances $\left(\mathrm{g}^{-1}\right)$ were calculated.

\section{Trace elements and mineralogy}

The concentrations of selected trace elements $(\mathrm{Ni}, \mathrm{Cu}, \mathrm{Zn}$, As, $\mathrm{Rb}, \mathrm{Sr}, \mathrm{Zr}, \mathrm{Pb}, \mathrm{Th}, \mathrm{U})$ were determined in 48 powdered samples at the University of Heidelberg (Germany) with the Energydispersive Miniprobe Multi-element Analyzer ('EMMA'; this Xray fluorescence analyser was developed by Andriy Cheburkin (see Cheburkin \& Shotyk, 1996, for details)); it is not subject to matrix interferences, and the trace element analyses show very low detection limits (see Supplementary Material). The EMMAXRF analyses were calibrated with several NIST reference materials and the relative analytical error is $<10 \%$.
The bulk rock mineralogy was determined at the University of Erlangen (Germany) on powdered samples (grain size $<10 \mu \mathrm{m}$ ) with a Siemens-Bruker D5000 X-ray diffractometer. This instrument is fitted with a copper tube $(\mathrm{CuK} \alpha=1.54178 \AA$ ), operating at $40 \mathrm{kV}$ and $35 \mathrm{~mA}$, and a post-diffraction graphite monochromator. Samples were side-loaded into a holder for random orientation and scanned from $5^{\circ}$ to $65^{\circ} 2 \Theta$ in steps of $0.02^{\circ}$ and 4 seconds scanning time. The X-ray diffractograms were evaluated by quantitative Rietveld analysis with BRUKER AXS TOPAS 4.0 software. The TOPAS Rietveld software provided very good fits of the diffractograms and the observed weighted residual errors $R_{w p}$ are generally lower than $8 \%$. The relative analytical error as determined by a comparison with several artificial mixtures and using $\mathrm{ZnS}$ as an internal standard is $<3 \%$.

\section{BIOSTRATIGRAPHY}

Planktic foraminifera

Planktic foraminifer biostratigraphy was studied by Sprong et al. (2009) by applying the biozonation criteria of Berggren \& Pearson (2005). The studied interval covers planktic foraminiferal Zones P2 and P3 and the lower part of P4 (Fig. 2b). The base of the section is in Zone P2, identified by the occurrence of Praemurica uncinata (Bolli, 1957). Subzones P3a and P3b were identified by the lowest occurrences (LOs) of their respective markers, i.e. Morozovella angulata (White, 1928) (P3a; $3.5 \mathrm{~m}$ ) 


\begin{tabular}{|c|c|c|c|c|c|c|c|}
\hline taxa & IN & MN & ON & B & & axis 1 & axis 2 \\
\hline Lenticulina spp. costate & & & & & 1,4 & 2.461 & 0.098 \\
\hline non-calcareous agglutinated taxa & & & & & $1,2,4$ & 2.317 & -0.831 \\
\hline Ammodiscus cretaceus & & & $\ldots$ & & 1,2 & 1.429 & -0.752 \\
\hline Neoeponides duwi & & & & & 1,2 & 1.163 & 2.806 \\
\hline agglutinated sp. B & & & & & & 0.991 & -0.694 \\
\hline Bulimina ovata-quadrata & $-\ldots$ & & & & 2,4 & 0.830 & -0.389 \\
\hline Siphogenerinoides esnehensis & & - & & & 1 & 0.434 & 1.113 \\
\hline Nodosaria spp. costate & & & & & 1 & 0.406 & 0.303 \\
\hline Stilostomella plummerae & & & & & 1,2 & 0.136 & 0.894 \\
\hline Marginulinopsis spp. & & & & & 1,2 & 0.055 & 0.538 \\
\hline Lenticulina spp. smooth & & & & & $1,2,3$ & 0.000 & 0.208 \\
\hline Bulimina strobila/farafraensis & $-\ldots$ & & & & 1,4 & -0.035 & 0.725 \\
\hline Anomalinoides midwayensis & & & & & 2,4 & -0.181 & -0.088 \\
\hline Alabamina midwayensis & $-\ldots$ & & & $-\ldots$ & $1-4$ & -0.191 & 0.201 \\
\hline Bulimina midwayensis & $\ldots$ & & & $\ldots$ & $1-4$ & -0.215 & 0.056 \\
\hline Tappanina selmensis & & & & & 2 & -0.222 & 0.310 \\
\hline Hansenisca girardanus & $\ldots$ & & & ...- & $1,2,4$ & -0.233 & 0.120 \\
\hline Oridorsalis plummerae & & & & $\ldots$ & $1-4$ & -0.245 & 0.028 \\
\hline Sporobulimina eocaena & & & & & $1,3,4$ & -0.247 & 0.095 \\
\hline nodosariids & & & & & 1,2 & -0.252 & -0.065 \\
\hline monothalamous taxa & & & & & & -0.278 & -0.075 \\
\hline Valvalabamina depressa & $\ldots$ & & & -... & $1-4$ & -0.294 & -0.079 \\
\hline Anomalinoides praeacutus & & & & -... & $1,2,4$ & -0.321 & 0.021 \\
\hline Cibicidoides cf. C. hyphalus & & & & & $1,3,4$ & -0.333 & -0.076 \\
\hline Angulogavelinella avnimelechi & & & & & $1,3,4$ & -0.336 & -0.156 \\
\hline Spiroplectinella dentata & & & & 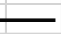 & 1,2 & -0.340 & -0.131 \\
\hline Cibicidoides pseudoacutus & & & &.-- & $1-4$ & -0.347 & -0.182 \\
\hline Valvalabamina planulata & $-\ldots$ & & & & $1,3,4$ & -0.359 & 0.007 \\
\hline Alabamina cf. A. creta & & & & — & 1 & -0.360 & 0.044 \\
\hline Gyroidinoides globosus & & & & — & 1 & -0.374 & -0.111 \\
\hline Cibicidoides rigidus & & & & & 3,4 & -0.388 & -0.177 \\
\hline Gyroidinoides sp. A & & & & & & -0.389 & -0.079 \\
\hline Pullenia jarvisi group & & & & & 1 & -0.393 & -0.195 \\
\hline Cibicidoides alleni & & & & & 1 & -0.395 & -0.294 \\
\hline Loxostomoides applinae & .... & & & -... & $=1,2,4$ & -0.432 & -0.132 \\
\hline Gyroidinoides cf. G. tellburmaensis & & & 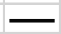 & & 2 & -0.433 & -0.109 \\
\hline Globocassidulina subglobosa & & & & & $1,3,4$ & -0.450 & -0.162 \\
\hline Tritaxia midwayensis & & & & -... & 1,2 & -0.460 & -0.186 \\
\hline Quadrimorphina spp. & & & - & & 2 & -0.462 & -0.109 \\
\hline Anomalinoides rubiginosus & & & & $-\ldots$ & 1,2 & -0.468 & -0.190 \\
\hline Pulsiphonina prima & & & & & 1,3 & -0.469 & -0.191 \\
\hline Eponides lunatus & & & & & & -0.476 & -0.058 \\
\hline Gaudryina pyramidata & & & & & & -0.477 & -0.287 \\
\hline Siphogenerinoides elegantus & & & & .... & $1,2,4$ & -0.482 & -0.317 \\
\hline Valvulineria? insueta & & & & & & -0.484 & -0.318 \\
\hline Osangularia plummerae & & & & & $1-4$ & -0.485 & -0.294 \\
\hline Spiroplectinella knebeli & & & & & 1,2 & -0.499 & -0.167 \\
\hline Anomalinoides affinis & & & & & $1,2,4$ & -0.504 & -0.214 \\
\hline Gavelinella beccariiformis & & & & & 1 & -0.526 & -0.326 \\
\hline Cibicidoides succedens & & & & $\ldots$ & $1,2,4$ & -0.528 & -0.295 \\
\hline Coryphostoma cf. C. midwayensis & & & & & 1 & -0.532 & -0.296 \\
\hline Anomalinoides susanaensis & & & & --- & 1,2 & -0.534 & -0.319 \\
\hline Nuttallides truempyi & & & & - & 1 & -0.537 & -0.268 \\
\hline
\end{tabular}

Fig. 5. Correspondence analysis (CA). Columns 2-5, bathymetrical ranges in North Africa of most taxa used in CA, with literature references in column 6 (1, Speijer \& Schmitz, 1998; 2, Schnack, 2000; 3, Ernst et al., 2006; 4, Stassen et al., 2009). IN, inner neritic palaeodepths of $<50 \mathrm{~m}$; MN, middle neritic - palaeodepths of 50-100 m; ON, outer neritic - palaeodepths of 100-200 m; B, bathyal - palaeodepths of $>200 \mathrm{~m}$. The two final columns indicate the taxon loadings on $\mathrm{CA}$ axes, arranged according to the values on CA axis 1 .

and Igorina albeari (Cushman \& Bermudez, 1949) (P3b; $8.05 \mathrm{~m}$, $15 \mathrm{~cm}$ below LDE bed I). I. albeari is the earliest igorinid developing a slight keel on the last chambers (cf. Sprong et al., 2009, Fig. 4, 10-12; Pl. 1, figs 4-6); in agreement with the concept of Quillévéré et al. (2002). The typical, large Globanomalina pseudomenardii Bolli, 1957, a marker of Zone P4 (Olsson et al., 1999), was not encountered, although small
Globanomalina specimens $(<125 \mu \mathrm{m})$, referred to as $G$. cf. pseudomenardii (Pl. 1, figs. 1-3) occur from $11.9 \mathrm{~m}$ upward. Following Speijer (2003a), the LO of Morozovella velascoensis (Cushman, 1925) was used to approximate the base of Zone P4 (13.9 m; indicated as 'P4' in Fig. 2b) because M. velascoensis is traditionally thought to appear approximately simultaneously with G. pseudomenardii (e.g. Blow, 1979; Toumarkine \& Luterbacher, 1985). However, M. velascoensis may appear somewhat below the base of Zone P4 (Premoli Silva et al., 2003; Steurbaut \& Sztrákos, 2008) or even closer to the base of P3b (Olsson et al., 1999).

\section{Calcareous nannofossils}

According to the biozonation criteria of Martini (1971), the studied part of section Qreiya 3 spans Zone NP4 and the lower part of Zone NP5 (Fig. 2b). Following the zonation scheme of Varol (1989), the studied sequence covers Zones NTp6 to NTp9, some of which are subdivided into subzones. These zones and subzones have also been identified in correlative Danian sections in Egypt (Youssef, 2009) and in Tunisia (Steurbaut et al., 2000; Guasti et al., 2006; Van Itterbeeck et al., 2007; Sprong et al., 2009). The (sub-) zonal boundaries are marked by the highest occurrence (HO) of Neochiastozygus eosaepes Perch-Nielsen, 1981 (NTp6/NTp7), and the respective LOs of Chiasmolithus edentulus van Heck \& Prins, 1987 (NTp7A/NTp7B), Sphenolithus primus Perch-Nielsen, 1971 (NTp7/NTp8), Fasciculithus billii Perch-Nielsen, 1971 or F. ulii Perch-Nielsen, 1971 (NTp8A/ NTp8B), and F. janii Perch-Nielsen, 1971 or F. pileatus Bukry, 1973 (NTp8B/NTp8C).

The NTp6/NTp7 Zonal boundary is situated $1 \mathrm{~m}$ above the base of the section and slightly postdates the $\mathrm{HO}$ of Fasciculithus magnus Bukry \& Percival, 1971 (at $\sim 0.7 \mathrm{~m}$ ). Subzone NTp7A contains rich and highly diverse nannofossil assemblages with Fasciculithus. The base of Subzone NTp7B is positioned at $7 \mathrm{~m}$. It is marked by a series of more-or-less coinciding nannofossil events, including the LOs of C. edentulus, small Fasciculithus taxa (F. chowii Varol, 1989 and others = first Fasciculithus radiation), medium-sized Toweius Hay \& Mohler, 1967, and the start of the consistent occurrence of Pontosphaera Lohmann, 1902. The first specimens of Sphenolithus primus, defining the NTp7/NTp8 boundary, are recorded at 10.65 m. Fasciculithus ulii and $F$. janii, maring the boundaries of Subzones NTp8A/ NTp8B and NTp8B/NTp8C, first appear at $13.0 \mathrm{~m}$ and $13.45 \mathrm{~m}$, respectively. The LOs of $F$. ulii and $F$. janii mark the second radiation in Fasciculithus and $F$. tympaniformis Hay \& Mohler, 1967, the marker of the base of Zone NP5, appears in low numbers from $13.9 \mathrm{~m}$ onward, in association with relatively frequent $F$. pileatus and $F$. involutus Bramlette \& Sullivan, 1961.

\section{Stratigraphical position of the LDE beds}

The contact between the carbonate-poor level underlying the LDE and lower LDE bed I is sharp in the Qreiya 3 section, and may represent an unconformity. Therefore, and contrary to Soliman \& Obaidalla (2010) we do not include this carbonatepoor interval in the LDE.

The base of LDE bed I is $8.20 \mathrm{~m}$ above the base of the section (Fig. 2) in lower planktic foraminifer Zone P3b (LO of I. albeari at $8.05 \mathrm{~m}$ : Sprong et al., 2009), in calcareous nannofossil Zone NP4 (Martini, 1971) and in Subzone NTp7B (Varol, 1989; the 
LOs of C. edentulus and small Fasciculithus spp. coinciding in the section at $7 \mathrm{~m}$ ). Planktic foraminifer biozonation in this interval is somewhat problematic due to differing taxonomical concepts (e.g. Arenillas et al., 2008; Sprong et al., 2009). The most reliable calcareous nannoplankton datums, according to Dinarès-Turell et al. (2010: 1st and 2nd radiation of Fasciculithus, LO of $C$. edentulus and LO of $F$. tympaniformis), are recognized in section Qreiya 3 and, on the basis of these datums, the section can be correlated to the Zumaia section in Spain (Bernaola et al., 2009). In 2008, the position of the Global Boundary Stratotype Section and Point (GSSP) of the basal Selandian at the base of the Itzurun Fm. in Zumaia was ratified (Schmitz et al., 2008; Bernaola et al., 2009; see https:// engineering.purdue.edu/Stratigraphy/gssp/); thereby replacing the conventional positioning of the Danian-Selandian (D-S) boundary at the P2/P3 boundary (e.g. Berggren et al., 1995; Steurbaut et al., 2000). Biostratigraphically, the newly defined Danian-Selandian boundary is situated between the second radiation of Fasciculithus, and the LO of $F$. tympaniformis marking the NP4/NP5 boundary (Schmitz et al., 2008; Bernaola et al., 2009). Consequently, the LDE beds are of late Danian age; they correlate with the lithological transition from the Crowded Member to the Stratified Member of the Aitzgorri Fm. at Zumaia, about $10 \mathrm{~m}$ below the D-S boundary (Steurbaut \& Sztrákos, 2008; Bernaola et al., 2009; Sprong et al., 2009). This stratigraphical position is in agreement with chemostratigraphical correlations on the basis of carbon isotope records (Bornemann et al., 2009). Westerhold et al. (2011; using tuning option 1 in Westerhold et al., 2008) correlate the LDE with both the 'CIE-DS1' of Arenillas et al. (2008) and the 'Top Chron C27n event' of Westerhold et al. (2008), placing it at the very top of Chron C27n and the basis of Chron C26r (eccentricity cycle 37 in Zumaia: Dinarès-Turell et al., 2010) and estimate the duration of the LDE at $\sim 200 \mathrm{ka}$, which is in agreement with the $191 \mathrm{ka}$ estimated by Bornemann et al. (2009). The LDE postdates the Dan-C2 event (Quillévéré et al., 2008; Coccioni et al., 2010) and precedes the Mid Paleocene Biotic Event (MPBE) or Late Palaeocene Biotic Event (LPBE) (Westerhold et al., 2008, 2011; Marcantonio et al., 2010).

\section{RESULTS}

\section{Foraminifera}

Benthic foraminifera are moderately to well preserved below and above the LDE and the assemblages are rather diverse (Fig. 4). Some $25 \%$ of the species recorded have been described from bathyal open-marine environments (Fig. 5). The relative abundances of the bathyal species decrease towards the LDE, and Gavelinella beccariiformis (White, 1928) disappears above $7.5 \mathrm{~m}$. Absolute abundances of planktic and benthic foraminifera (PFN, BFN) drop to extremely low values towards the LDE, the diversity decreases and the P/B ratio drops to $13 \%$ (Fig. 4). PFN, fluctuating between 200 and 4000 below and above the LDE drop immediately below, and in the lower part of LDE bed I, where PFN are $<40$ specimens $\mathrm{g}^{-1}$; whereas pyritized moulds of planktic foraminiifera are abundant. PFN increase in LDE bed II, and show peak abundance $>10000$ at $8.29 \mathrm{~m}$ (top of LDE bed I). A maximum of $\sim 9000$ planktic specimens $\mathrm{g}^{-1}$ between
$11 \mathrm{~m}$ and $14 \mathrm{~m}$ is followed by a decrease below 500 in the top $2.5 \mathrm{~m}$ of section. BFN generally fluctuate between 100 and 400 below and above the LDE, but only $\sim 10$ benthic foraminifera $\mathrm{g}^{-1}$ occur in the $15 \mathrm{~cm}$ just below the LDE beds, and LDE bed I is barren of in situ benthic foraminifera. In LDE bed II BFN increase to a temporary maximum of $\sim 535$ specimens $\mathrm{g}^{-1}$ at $8.4 \mathrm{~m}$.

The relative abundances of non-calcareous agglutinated benthic foraminifera increase from $<5 \%$ to $20-80 \%$ in the carbonate-poor interval below the LDE beds (7.8-8.2 m). Relatively common bathyal species, such as Gavelinella beccariiformis, Osangularia plummerae Brotzen, 1940 and Anomalinoides affinis (Hantken, 1875), disappear below the LDE, whereas the costate Siphogenerinoides esnehensis (Nakkady, 1950) has its lowest occurrence there. In LDE bed II Neoeponides duwi temporarily dominates the benthic assemblage ( $>50 \%)$ together with Siphogenerinoides elegantus (Plummer, 1927), S. esnehensis and stout lenticulinids. Above the LDE, at $9.5 \mathrm{~m} \mathrm{G}$. beccariiformis returns, but its abundance remains $<10 \%$. In contrast, Nuttallides truempyi (Nuttall, 1930) is more common above than below the LDE. No extinctions of benthic foraminifera are recorded (see Supplementary Material).

Correspondence analysis (CA) separates the LDE and the carbonate-poor interval below the LDE from the background samples (Fig. 6). The first two axes of the CA together explain $\sim 49 \%$ of the variance in the data set: $29.6 \%$ and $19.1 \%$, respectively. Running CA without the sample at $8.25 \mathrm{~m}$ (LDE bed I; with downwards bioturbated foraminifera) gives the same result. Relative abundances summed according to water-depth preferences (Fig. 5) suggest shallowing associated with the LDE interval (Fig. 7a, b). The high abundances of non-calcareous agglutinated taxa below and in the LDE are not observed in calcarenite $\mathrm{C} 1$ cutting through the LDE (Fig. 7c).

\section{Calcareous nannofossils}

The nannofossil assemblages are moderately to very well preserved up to $70 \mathrm{~cm}$ below the LDE $(0.0-7.5 \mathrm{~m})$ and moderately diverse (16 to 22 taxa). Small Prinsius spp. dominate these samples (40-75\%) (Fig. 8; see Supplementary Material). Other commonly occurring taxa are Coccolithus spp. (17-45\%), Toweius sp. (1-9\%), Ellipsolithus spp. (1-8\%), Neochiastozygus spp. $(1-7 \%)$ and Cruciplacolithus spp. (1-4\%). The preservation of the nannofossils rapidly deteriorates towards the LDE, and in this interval the assemblages are dominated by Coccolithus pelagicus (Wallich, 1877) (30-60\%), occurring together with $C$. subpertusus (Hay \& Mohler, 1967) (4-13\%), small Prinsius spp. (4-25\%), Toweius spp. (3-19\%) and Pontosphaera sp. (4-10.5\%). Rare, small Fasciculithus spp. appear in this interval. Absolute abundances drop from $>1 \times 10^{9}$ to $<1 \times 10^{7}$ specimens $\mathrm{g}^{-1}$ between $8.05 \mathrm{~m}$ and $8.2 \mathrm{~m}$, and remain low in LDE bed I and the lower part of LDE bed II.

In the LDE beds, the nannofossils are moderately preserved and the number of taxa ranges from 5 to 17 . Overall the robust C. pelagicus-C. subpertusus group dominates the assemblage (40-85\%). From $8.5 \mathrm{~m}$ upwards, the absence of signs of overgrowth and etching indicates improving nannofossil preservation. The assemblages are moderately preserved and diversified (10-27 taxa), and are again dominated by small Prinsius spp. 

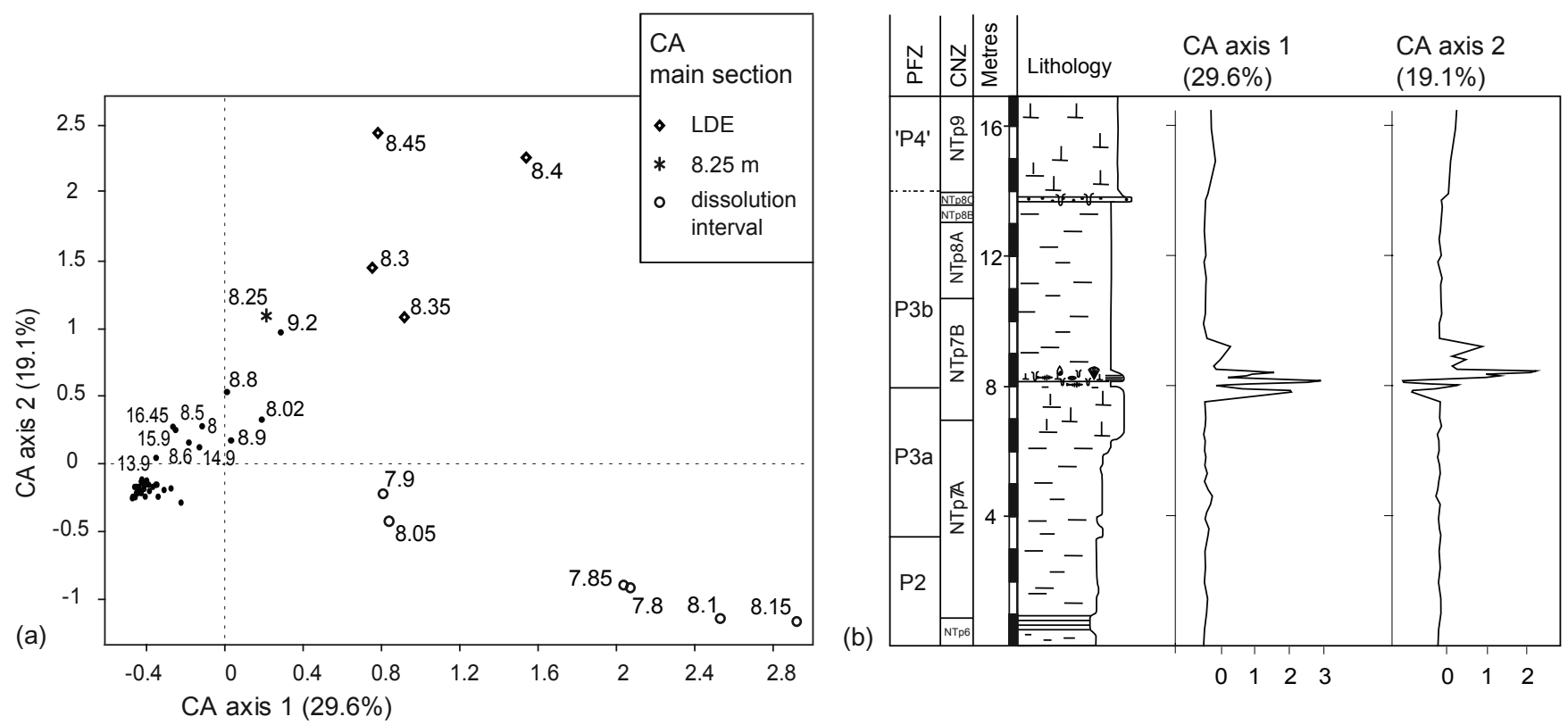

Fig. 6. Correspondence analysis (CA). Barren sample at $8.2 \mathrm{~m}$ in main section (LDE bed I) excluded. Sample at $8.25 \mathrm{~m}$ (LDE bed I, containing downwards bioturbated foraminifera) indicated by star. (a) Bi-plot of correspondence analysis (CA) axes 1 (explaining $29.6 \%$ of the variance) and $2(19.1 \%$ of the variance). The dissolution interval, characterized by $>20 \%$ non-calcareous agglutinated taxa (NC), the LDE and the 'background' outer neritic $(\mathrm{ON})$ groups are separated by CA. (b) Trends in the first and second axes of CA, together explaining $\sim 49 \%$ of the variance in the dataset.
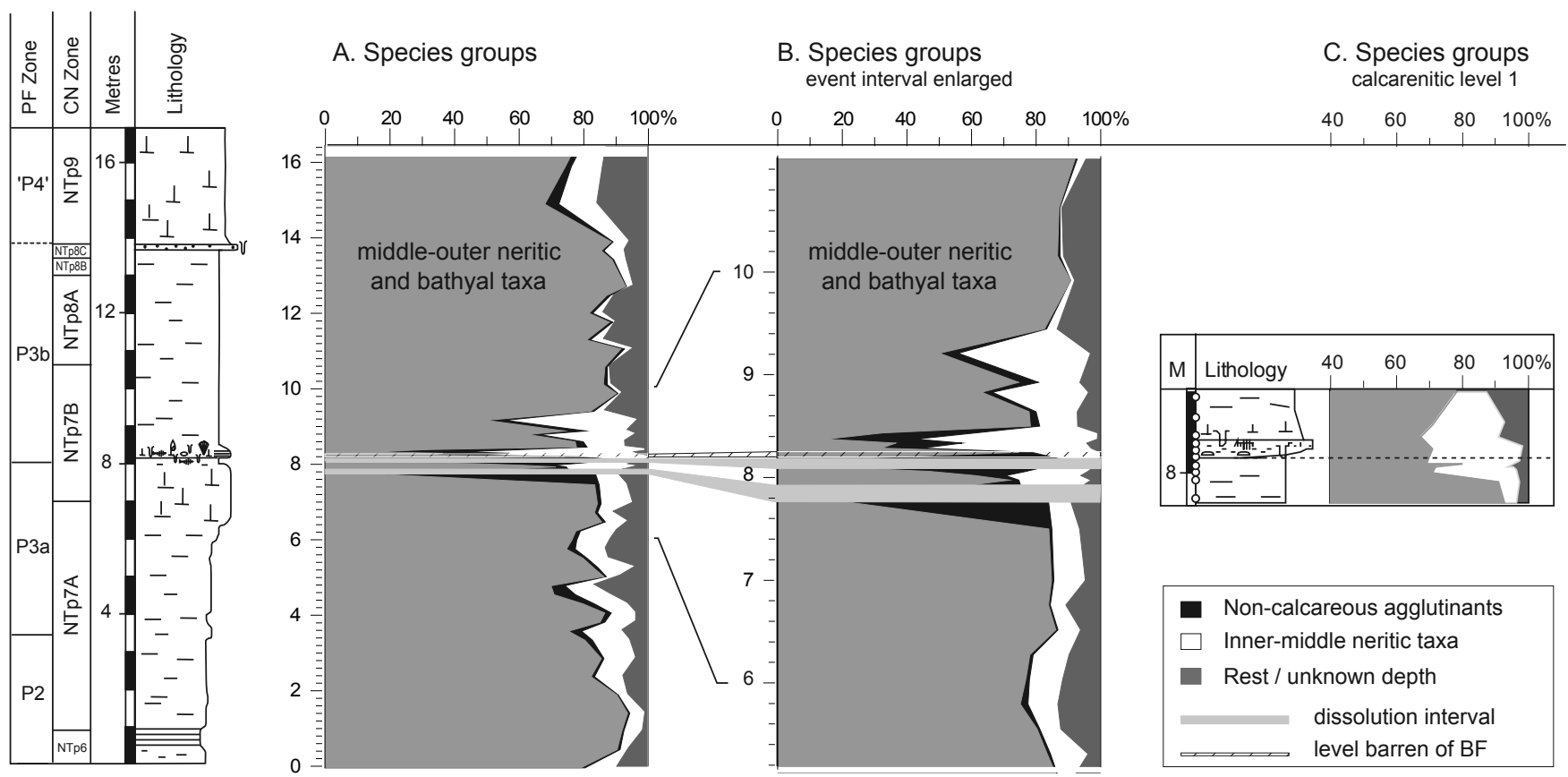

Fig. 7. Benthic foraminifera abundances across the LDE. Relative abundances are summed per bathymetrical group (see Fig. 5). (A) Relative abundances of bathymetrical groups throughout the Qreiya 3 section. (B) As (A) but LDE interval enlarged. (C) Relative abundances of bathymetrical groups across calcarenite $\mathrm{C} 1$, for comparison with the LDE interval in the main section. Non-calcareous agglutinated taxa do not exceed $2.5 \%$ relative abundance in $\mathrm{C} 1$.

(40-80\%). Other frequently occurring taxa are C. pelagicus (8-30\%), C. subpertusus (1-9\%) and Toweius sp. (9\%).

\section{Mineralogy and trace element geochemistry}

The mineralogical composition of the shales is dominated by phyllosilicates (50-70 wt\%; Fig. 9; see Supplementary Material).
Calcite is the second dominant component (15-50 wt $\%)$, whereas the quartz and feldspar content is low $(<4$ and $<6 \mathrm{wt} \%$, respectively). Substantial changes in the mineralogy occur $\sim 35 \mathrm{~cm}$ below the LDE, where the drop in the calcite content to less than $3 \mathrm{wt} \%$ marks the base of the dissolution level. Within LDE bed I the calcite content rises abruptly to $>50 \mathrm{wt} \%$. In 


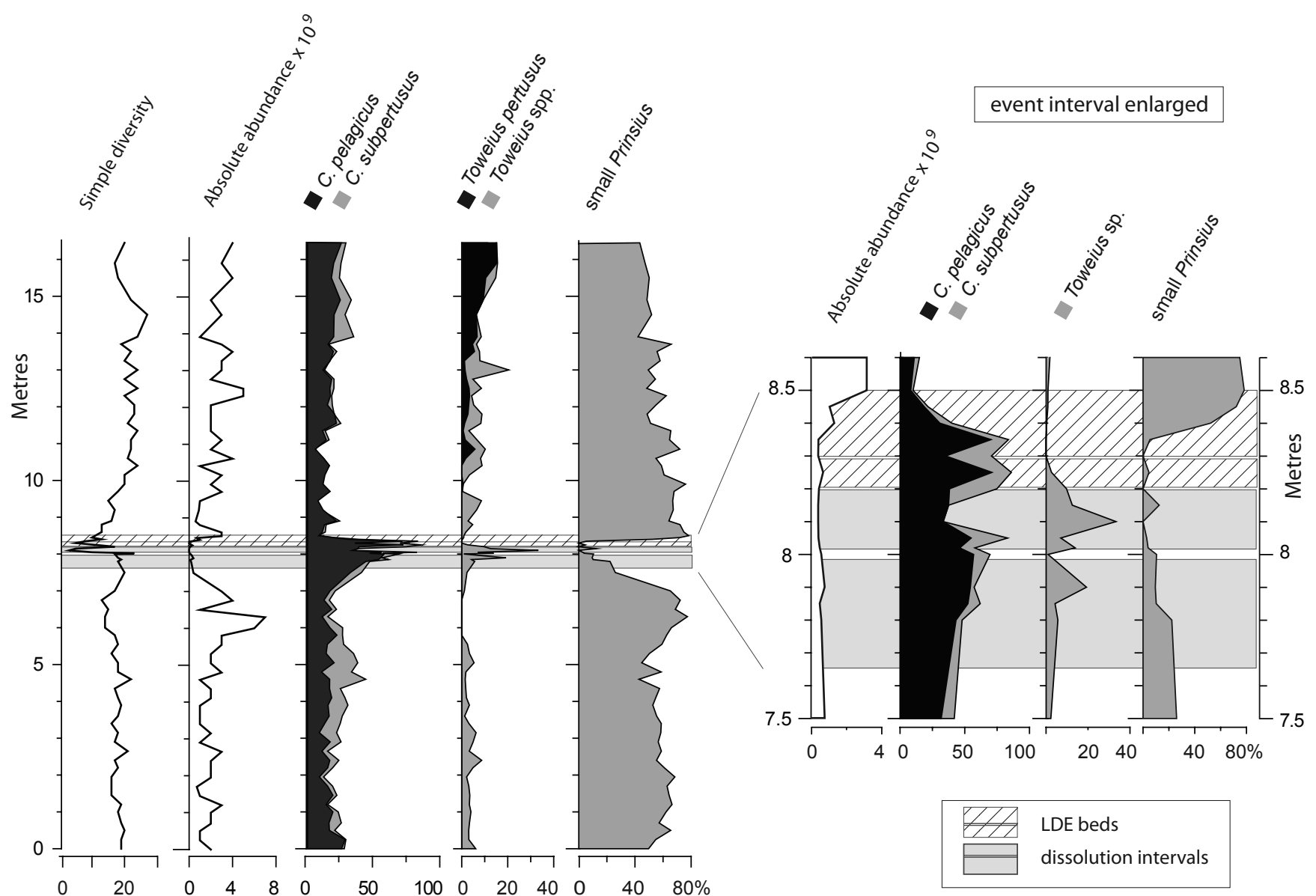

Fig. 8. Relative abundances of calcareous nannofossil taxa, showing the distribution throughout the Qreiya 3 section, with an enlargement of the LDE interval on the right.

addition, the LDE beds show slightly higher amounts of quartz (up to $4 \mathrm{wt} \%$ ), iron oxides, pyrite and anhydrite compared to the Dakhla shales. Above the LDE the calcite content rises to $\sim 75 \mathrm{wt} \%$ in Zone 'P4'.

The $\mathrm{Th} / \mathrm{U}$ ratio, a reliable proxy for palaeoredox conditions (e.g. Dypvik \& Harris, 2001), is well above 1 below the LDE (Fig. 9; see Supplementary Material). It drops sharply in the 15 $\mathrm{cm}$ below the LDE and remains $<0.1$ in the LDE beds, rising again to values $\sim 1$ between $8.5 \mathrm{~m}$ and $10 \mathrm{~m}$. In the upper part of the section $\mathrm{Th} / \mathrm{U}$ remains $<1$. In concert with the $\mathrm{Th} / \mathrm{U}$ ratio, the redox-sensitive trace elements $\mathrm{U}, \mathrm{As}, \mathrm{Ni}, \mathrm{Cu}$ and $\mathrm{Zn}$ show a sharp $\sim 10$-fold increase in the LDE beds.

$\mathrm{The} \mathrm{Zr} / \mathrm{Rb}$ ratio, an indicator for relative grain-size changes (e.g. Dypvik \& Harris, 2001) fluctuates between 2 and 2.5 in the lower $6 \mathrm{~m}$ of the section, and increases towards the LDE. A maximum ratio of 3.1 is found in bed $\mathrm{I}$ before the ratio drops to low values of $\sim 2$ in LDE bed II. Above the LDE beds the $\mathrm{Zr} / \mathrm{Rb}$ ratio remains $\sim 2.5$ and, from 13 m upwards, oscillates around 2 .

\section{Calcarenite beds $\mathbf{C 1}-\mathbf{C 3}$}

The lens-shaped calcarenitic beds $\mathrm{C} 1-\mathrm{C} 3$ are interpreted as channel fills, containing reworked material. In general these beds contain higher benthic and planktic foraminiferal numbers (see Supplementary Material). Whereas BFN drop towards the LDE in the main section, they rise in calcarenite $\mathrm{C} 1$ to a maximum of nearly 4000 specimens $\mathrm{g}^{-1}$ at $8.25 \mathrm{~m}$. Calcarenites $\mathrm{C} 2$ and $\mathrm{C} 3$ both contain levels with relatively high $\mathrm{BFN}$ compared to the main section (C2: 1515 (11.4 m) vs. 246 (11.3 m); C3: 2026 vs. 1281 , both at $13.7 \mathrm{~m}$ ). The relative abundance of non-calcareous agglutinated taxa is $\leq 2.5 \%$ in calcarenite $\mathrm{C} 1$, but an increased abundance of $N$. duwi and associated taxa is observed in calcarenite $\mathrm{C} 1$, indicating resedimentation of material from LDE bed II into the channel fill.

\section{DISCUSSION}

\section{Onset of the LDE}

Prior to the LDE our data point to an oligo-mesotrophic, well-oxygenated outer neritic to upper bathyal marine environment, sustaining rather diverse nannofloral and benthic foraminiferal assemblages. About $2 \mathrm{~m}$ below the LDE beds, coarsening of the sediments is indicated by the increasing $\mathrm{Zr} / \mathrm{Rb}$ ratio, and the calcium carbonate content decreases. From about $70 \mathrm{~cm}$ below the LDE beds, the shift to lighter $\delta^{13} \mathrm{C}$ coincides with changes in the abundance patterns of the nannoflora and benthic foraminifera (Figs 4, 7, 8). The interval below the LDE consists of two levels $(7.85-8 \mathrm{~m}$ and $8.05-8.2 \mathrm{~m})$ characterized by $<3 \mathrm{wt} \%$ calcium carbonate, lowered $\mathrm{P} / \mathrm{B}$ ratios, as well as 


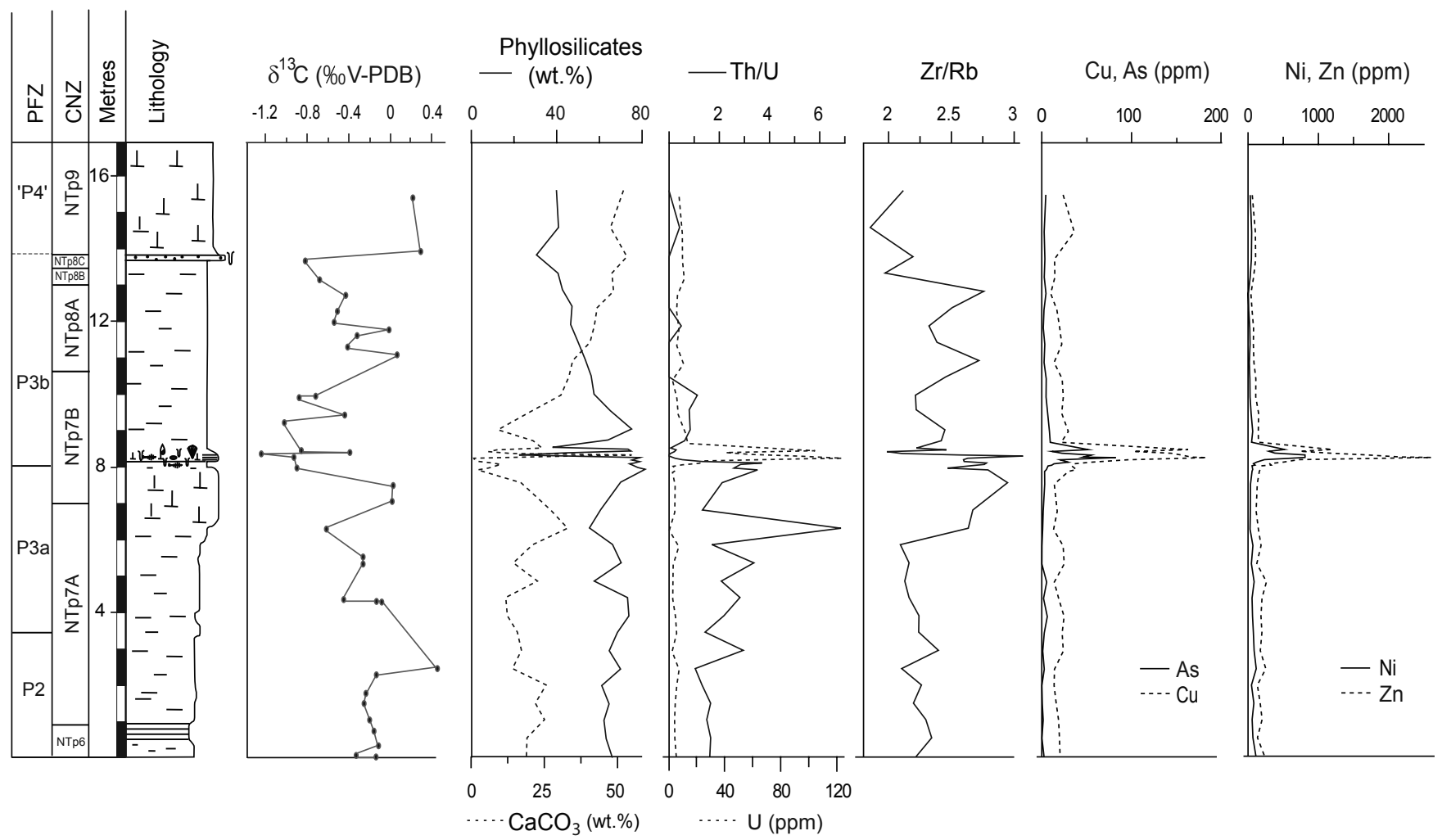

Fig. 9. Sediment geochemistry, showing (from left to right) the stable carbon isotopes, weight $\% \mathrm{CaCO}_{3}$, weight $\%$ clay minerals, major element ratios and redox-sensitive trace elements.

low diversity and absolute abundances of foraminifera and calcareous nannofossils (Figs 4, 8, 9). The nannofossil assemblages are dominated by robust Coccolithus species (Fig. 8). The benthic foraminiferal assemblages contain $20-80 \%$ noncalcareous agglutinated species (mainly Haplophragmoides spp. and trochamminids). Severe carbonate dissolution provides a parsimonious explanation for these observations.

In a thin level (8-8.05 m) dissolution of benthic foraminifera is less severe, indicated by higher benthic diversity, and lower dominance of the non-calcareous agglutinated taxa (Figs 4, 7). In this thin interval the relative abundance of outer neritic to bathyal species decreases to $<5 \%$, and Gavelinella beccariiformis and Nuttallides truempyi are not recorded, but there are no indications in the benthic fauna or the trace elements for dysoxia. The $\delta^{13} \mathrm{C}$ shifts $\sim 1 \%$ owards lighter values, but the changes in trace element concentrations below the LDE are relatively minor and probably largely associated with carbonate dissolution, and/or with leaching due to downward migration of a redox front; a diagenetic effect comparable to the "burningdown' of sapropels (e.g. Higgs et al., 1994; Thomson et al., 1995). The Th/U-ratio, reflecting redox conditions at the seafloor (Dypvik \& Harris, 2001), oscillates around 2 below $8.11 \mathrm{~m}$, suggesting well-oxygenated bottom waters, and then rapidly declines towards the LDE.

\section{The LDE}

Considering the low PFN, BFN and nannofossil abundances in the LDE beds, dissolution probably affected sediments deposited during the LDE, but the primary palaeoenvironmen- tal signal of the assemblages recorded during the event has been preserved.

Stable carbon isotopes. The negative carbon isotope excursion associated with the LDE in Egyptian sections (Bornemann et al., 2009; Fig. 9) can be correlated with Zumaia (Spain: Schmitz et al., 1996, 1997) and open-ocean stable carbon and oxygen isotope records (Arenillas et al., 2008; Bernaola et al., 2009; Bornemann et al., 2009; Westerhold et al., 2011). However, the magnitude of the excursion is larger in the Qreiya 3 section ( $>1 \%$ versus $0.5-1 \%$ at Zumaia and in the open-ocean records), and the double carbon isotope peak found at Shatsky Rise in the west-central Pacific (Westerhold et al., 2011) has so far not been resolved at the Qreiya 3 section. This may be due to the severe carbonate dissolution below the LDE and the absence of the species measured. From the oxygen isotope record at Shatsky Rise, Westerhold et al. (2011) estimate a bottom-water temperature rise of $\sim 2^{\circ} \mathrm{C}$. The authors mention the possibility of a causal relationship with the first phase of the North Atlantic Igneous Province.

Benthic anoxia: foraminifera and trace elements. Sedimentary lamination and the absence of benthic foraminifera in LDE bed I, in concert with organic enrichment, preservation of fish remains and presence of pyritized planktic foraminifera, point to temporary anoxia at the seafloor; an interpretation corroborated by the geochemical data. Very low Th/U-ratios in the LDE beds are due to significant uranium enrichment (Fig. 9). High uranium values are typical for anoxia (e.g. Dypvik \& Harris, 2001; 
Tribovillard et al., 2006) and high concentrations of other redoxsensitive trace elements, including $\mathrm{As}, \mathrm{Ni}, \mathrm{Cu}$ and $\mathrm{Zn}$ further support this interpretation (Fig. 9; Calvert \& Pedersen, 1993; Morford \& Emerson, 1999; Nijenhuis et al., 1999; Tribovillard et al., 2006; see also Soliman \& Obaidalla, 2010). In bed II the reappearance of benthic foraminifera and molluscs, trace element enrichment and the absence of lamination suggest at least intermittent availability of oxygen, enabling benthic repopulation. A low-diversity assemblage composed of rather robust, probably dissolution- and low oxygen-resistant foraminifera, including non-calcareous agglutinated taxa and Neoeponides duwi (Speijer, 2003b) dominates most of LDE bed II, but gives way to a more diverse assemblage upwards in bed II. The top of bed II $(8.45 \mathrm{~m})$ shows an increase in the redox-sensitive trace elements to levels approaching those in bed I, suggesting that a second brief anoxic interval occurred towards the end of the LDE. However, the aspect of the top centimetres of bed II and the correlation to channel $\mathrm{C} 1$ (Fig. 2) indicative of enhanced bottom currents, suggest some reworking and/or redeposition of sediments from the underlying LDE bed I. Comparing Bands 2 and 4 of the el-Qreiya bed in Soliman \& Obaidalla (2010, fig. 5) raises the suspicion that Band 4 of these authors may also contain material resedimented from Band 2.

Nannoflora. Coccolithus pelagicus is relatively resistant to dissolution (Raffi \& Rio, 1981), which explains its high relative abundance in the carbonate-poor interval preceding the LDE, and might in part explain its high relative abundance in the LDE beds. Eurytopic behaviour was suggested for $C$. pelagicus (Aubry, 1998). In addition, C. pelagicus has probably shifted its distribution since the Palaeogene (Haq \& Lohmann, 1976), rendering interpretations difficult. Today $C$. pelagicus is abundant in the arctic/subarctic and in high-productivity regions off river mouths (Cachao \& Moita, 2000) and in upwelling regions (Okada \& McIntyre, 1979). In the Pliocene-Quaternary C. pelagicus was found in sapropels (e.g. Müller, 1985; Negri et al., 2003), commonly associated with water-mass stratification (e.g. Nijenhuis et al., 1999). In Paleocene-Eocene times, C. pelagicus was common at low latitudinal equatorial sites (Okada \& Honjo, 1973). The abundance pattern of $C$. pelagicus across the LDE resembles the pattern across the PETM in Egypt (Monechi et al., 2000), which was interpreted as an increase in surface productivity (Speijer \& Wagner, 2002). In addition, the abundance patterns of $C$. pelagicus and C. subpertusus during the LDE, of which the latter is generally associated with warm waters (Aubry, 1998), resemble those at the PETM at Demerara Rise in the western Atlantic (Jiang \& Wise, 2006; Mutterlose et al., 2007). This suggests that increased productivity was associated with higher surface-water temperatures during the LDE.

In the upper part of LDE bed II the diversity and absolute abundance of nannoflora increase and the small Prinsius species dominate the nannofloral assemblages again, indicating both decreasing dissolution, and a return to more normal openmarine conditions.

\section{Recovery after the $\mathrm{LDE}$}

The $N$. duwi assemblage already decreases in abundance in LDE bed II and the diversity and $\% \mathrm{P}$ increase to pre-LDE values. The
PFN and the benthic foraminiferal assemblages are restored more gradually (Figs 4, 7). Extinctions of benthic foraminifera are not recorded, suggesting that the impact of the LDE on bottom-water environments was less severe than the impact of the PETM. The Th/U-ratio is generally below 1 and the uranium content is slightly higher than pre-LDE levels, suggesting slightly lower oxygen levels at the seafloor. The PFN are high in this interval (Fig. 4), suggesting increased productivity. In Zone ' $\mathrm{P} 4$ ' the $\mathrm{PFN}$ drop, coinciding with lowered $\mathrm{P} / \mathrm{B}$ ratios. The benthic foraminiferal assemblage changes significantly and Bulimina strobila Marie, 1941/farafraensis LeRoy, 1953 dominates in this interval. In recent environments, high abundances of buliminid taxa are commonly related to enhanced food levels or oxygen deprivation, or a combination of these factors (e.g. Corliss \& Chen, 1988; Jorissen et al., 1995).

\section{Sea-level across the LDE}

The $\mathrm{P} / \mathrm{B}$ ratio does not provide a reliable estimation of palaeodepth in the intervals affected by carbonate dissolution; as planktic and thin-walled, fragile benthic foraminifera will preferentially dissolve and more robust taxa will be enriched in the assemblage (e.g. Nguyen et al., 2009 and references therein). Alternatively, the relation of the benthic foraminifera assemblage composition with water depth may be used (Fig. 5). Well below and above the LDE, the abundances up to $25 \%$ of bathyal species such as Gavelinella beccariiformis, Nuttalides truempyi and Gyroidinoides globosus (von Hagenow, 1842) and the absence of (inner) neritic taxa (Figs 4, 7) indicate a palaeodepth of $\sim 150-250 \mathrm{~m}$ (outer shelf to upper bathyal; see Speijer, 2003a). The lower abundances $(<10 \%)$ of bathyal taxa directly below and above the LDE ( 7.5-9.5 m) suggest shallowing preceding, and deepening following, the LDE. Within the carbonate-poor interval below the LDE a thin level around $8 \mathrm{~m}$, where dissolution is not prominent, contains a moderately diverse assemblage with decreased $(<5 \%)$ abundances of typical bathyal to outer neritic taxa, such as G. globosus and Angulogavelinella avnimelechi (Reiss, 1952). Outer neritic species occur in this level, such as Osangularia plummerae and Cibicidoides pseudoacutus (Nakkady, 1950), together with increased abundances of shallower, neritic taxa, including $14-20 \%$ of the inner-middle neritic Siphogenerinoides esnehensis. LDE bed II (and the burrows penetrating from bed II down into bed I) contain high numbers of Neoeponides duwi and few other taxa, mainly restricted to neritic deposits. This benthic assemblage would indicate a water depth of $\sim 30-70 \mathrm{~m}$ (e.g. Schnack 2000; Speijer, 2003a). If the succession of benthic assemblages would be attributed solely to variations in water depth, shallowing and subsequent deepening would amount to $\sim 75-200 \mathrm{~m}$. However, the evidence for increased supply of organic matter and anoxia outlined above may have affected the abundances of bathyal species including $G$. beccariiformis and $N$. truempyi, considered to prefer more oligotrophic conditions than inferred for the Egyptian Paleocene shelf during the LDE (e.g. Widmark \& Speijer, 1997; Thomas, 1998). Therefore, extreme shallowing is a rather unlikely explanation for the temporary dominance of $N$. duwi within the LDE beds. The incursion of the $N$. duwi assemblage in Egyptian sections appears to occur in response to anoxia during the LDE (cf. Speijer, 2003a). Despite its size and stout test, $N$. duwi might be an opportunistic species, and its distribution may be driven 


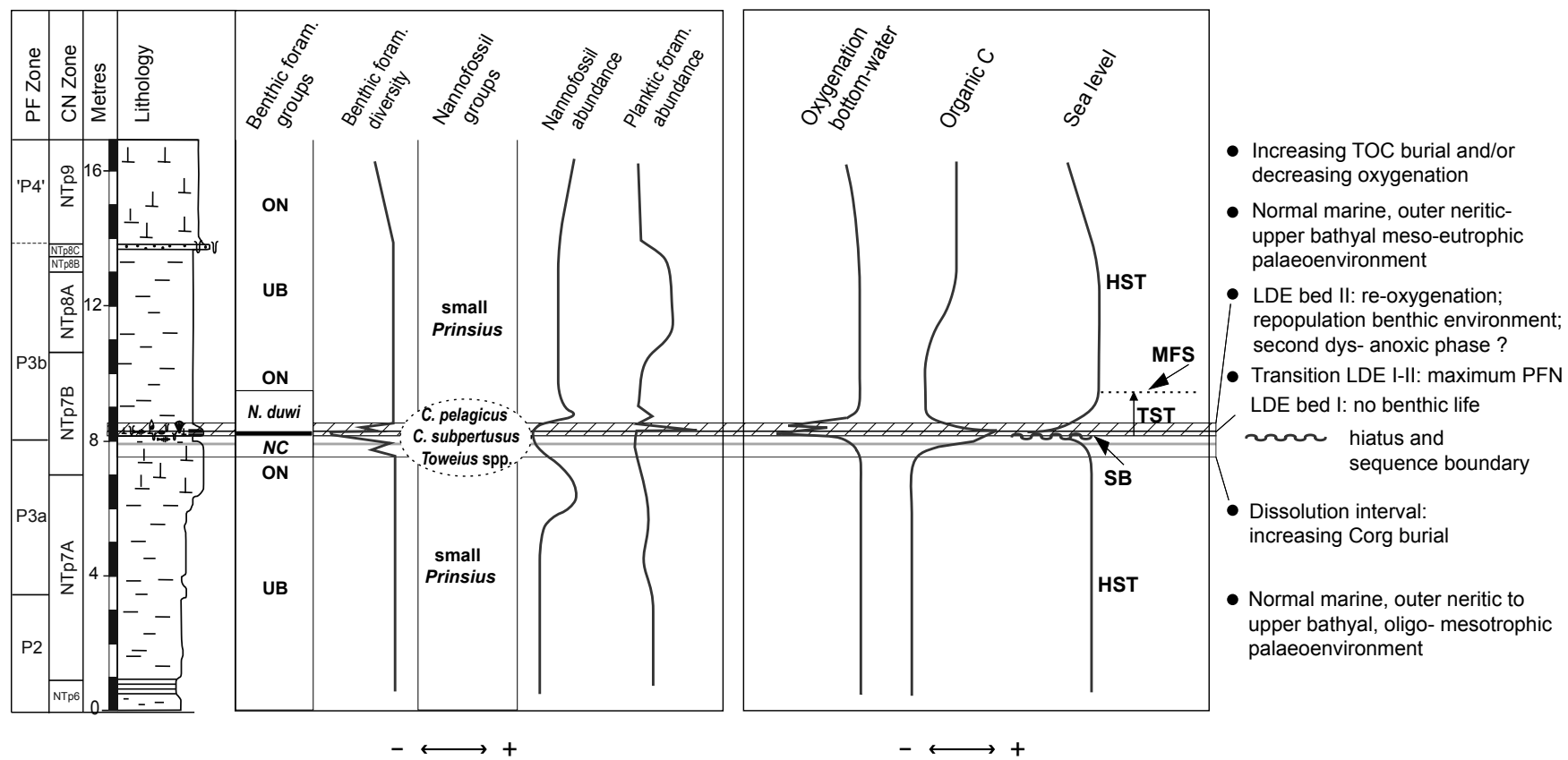

Fig. 10. Sketch summarizing the palaeoenvironmental reconstruction of the Late Danian Event beds at Qreiya-3. The transition from the underlying Dakhla Shales to the LDE beds is abrupt. The event beds are interpreted as representing a transgressive phase during a sea-level cycle. TOC, total organic carbon; $\mathrm{C}_{\mathrm{org}}$, organic carbon; $\mathrm{NC}$, non-calcareous agglutinated taxa; $\mathrm{ON}$, outer neritic; UB, upper bathyal. See text for further explanation.

by the 'delta effect' described by Pflum \& Frerichs (1976). We suspect that $N$. duwi is able to withstand oxygen depletion, favouring its rapid entry as one of the first - calcareous - species in formerly vacated environments. Although documented present-day early recolonizers are often agglutinated taxa (e.g. Hess et al., 2001; Koho et al., 2007), these taxa are too fragile to yield fossil analogues. Alternatively, recolonization sequences of the Paleocene may have been genuinely different from today's.

Since $N$. duwi appears not to be confined to a particular depth range, water depth estimations based on this species in a context of severe environmental changes, such as anoxia, are not reliable. Consequently, we base the magnitude of the sea-level cycle across the LDE on relative abundances of bathyal and outer neritic taxa, estimating it to be around $50 \mathrm{~m}$ maximum, fluctuating between upper bathyal and outer neritic.

\section{Sequence stratigraphy}

The inferred palaeoenvironmental changes associated with the deposition of the LDE beds are summarized in Figure 10. The increase in the $\mathrm{Zr} / \mathrm{Rb}$ ratio indicates that coarser sediments were deposited above $6.5 \mathrm{~m}$, in agreement with shallowing towards the LDE and an interpretation as a late, prograding part of a highstand systems tract (HST) (Dypvik \& Harris, 2001; Speijer, 2003a; Schulte \& Speijer, 2009). Seafloor anoxia during deposition of LDE bed I suggests that the LDE beds were deposited during a sea-level rise and, therefore, could be assigned to a transgressive systems tract (TST) directly overlying the HST. This would imply that the base of the LDE constitutes a sequence boundary (SB) without evidence for deposition during the sea-level lowstand; an observation that is typical for sequences on the Egyptian shelf (e.g. Speijer \& Wagner, 2002).
This would also suggest that an unconformity is present at the base of the LDE. However, the duration of the possible hiatus associated with this unconformity cannot be constrained here. In the interval above the LDE, a maximum flooding surface (MFS) may be positioned around $9.5 \mathrm{~m}$ and the sediments further upsection may represent a HST. The calcarenitic channel fills indicate occasional variations of bottom-water currents and are not related to changes in sea-level.

A relative sea-level fall before deposition of the LDE beds and a subsequent rise in sea-level is also observed at Gebel Aweina (Speijer \& Schmitz, 1998; Speijer, 2003a). In the area between Abu Tartur and Aswan a younger erosional surface (upper Zone P3a to lower P4 are missing), also observed at Gebel Aweina, seems to amalgamate with the older unconformity of the LDE, leading to a major hiatus, which was earlier related to a relative sea-level fall that started during early biochron P3a (Luger, 1985; Speijer 2003a).

\section{CONCLUSIONS}

The Qreiya 3 section comprises an almost complete upper Danian to lower Selandian succession in an outer neritic to upper bathyal depositional setting, and encompasses the Latest Danian Event (LDE: 8.20-8.45 $\mathrm{m}$ above base of section), characterized by anomalous lithology. Trace elements, nannofossils and benthic foraminifera indicate increased nutrient input and anoxic conditions in the lower part of the LDE (bed I). The upper part of the LDE (bed II) records intermittent oxygenation of the seafloor. Incursion of the $N$. duwi benthic foraminiferal assemblage in bed II is interpreted as repopulation during the recovery from anoxic conditions. Benthic foraminifera indicate shallowing preceding the LDE. LDE bed I was probably deposited during rapid relative sea-level rise. 


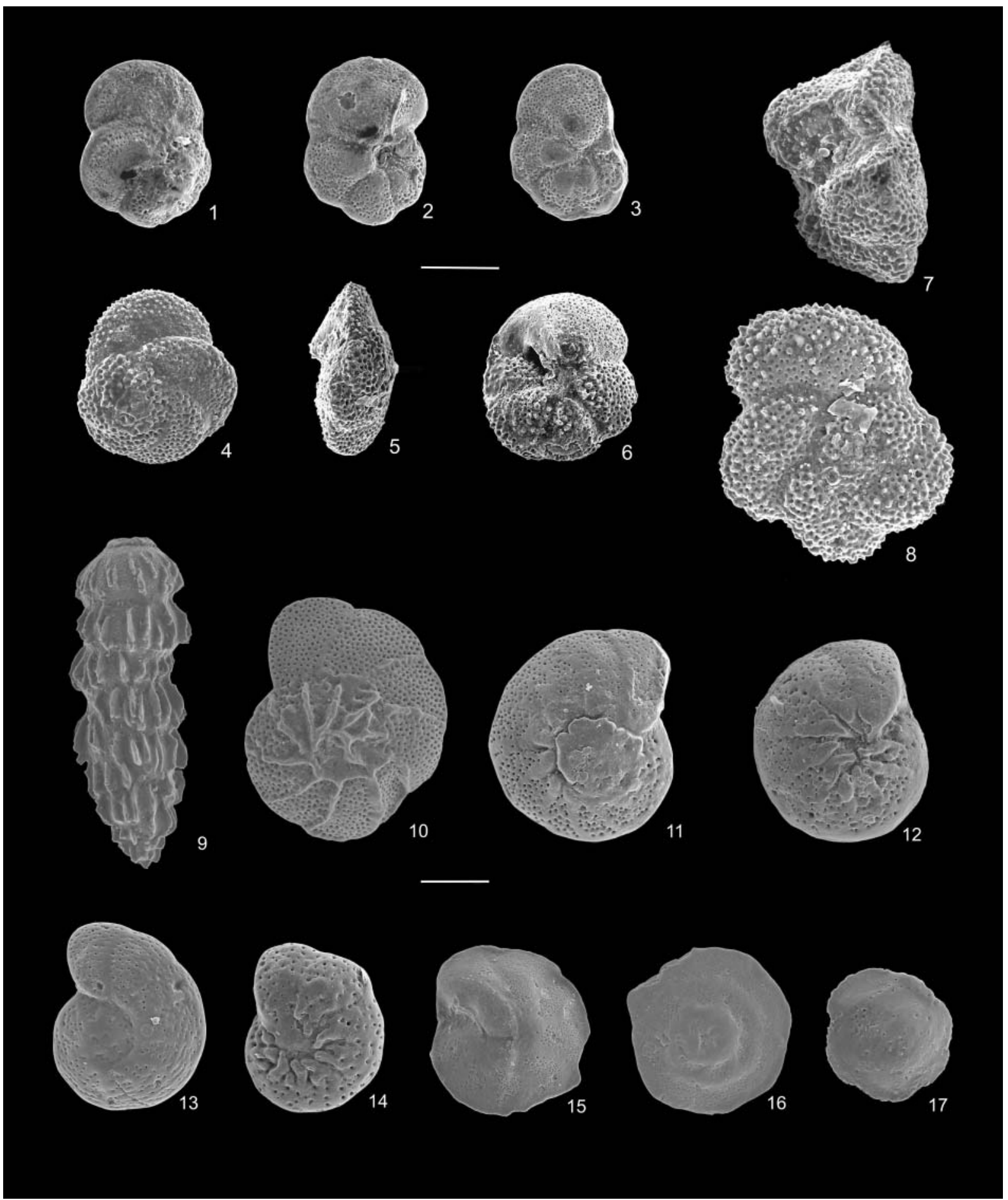

Explanation of Plate 1.

Typical planktic and benthic foraminifera in the Qreiya 3 section. figs 1-8. Biostratigraphical marker species. figs 1-3. Globanomalina cf. G. pseudomenardii: 1, spiral view, sample Q3-25 (12 m); 2, umbilical view, sample Q3-25 (12 m); 3, umbilical view, sample Q3-30 (14.5 m); figs 4-6. Igorina albeari: 4, spiral view, Q3 sample C1-4-0; 5, apertural view, Q3 sample C1-4-0; 6, umbilical view, sample Q3-44 (15.85 m); figs 7, 8. Morozovella angulata: 7, spiral view, sample Q3-16 (3.6 m); 8, apertural view, sample Q3-17 (3.9 m). figs 9-10. Benthic foraminifera from the LDE interval: 9, Siphogenerinoides esnehensis, sample Q3-35 (8.0 m); 10, Neoeponides duwi, spiral view, sample Q3-44 (8.40 m); figs 11-17. Benthic foraminifera with an outer neritic and bathyal habitat: 11, Cibicidoides pseudoacutus, spiral view, sample Q3-1 (0.0 m); 12, Angulogavelinella avnimelechi, umbilical view, sample Q3-9 (1.95 m); 13, Anomalinoides affinis, spiral view, sample Q3-20 (4.6 m); 14, Gavelinella beccariiformis, umbilical view, sample Q3-1 $(0.0 \mathrm{~m}) ; \mathbf{1 5}$, Osangularia plummerae, umbilical view, sample Q3-16 (3.6 m); 16, Nuttallides truempyi, spiral view, sample Q3-51 (9.45 m); 17, Pulsiphonina prima, spiral view, sample Q3-28 (6.5 m). Scale bars $100 \mu \mathrm{m}$; upper scale bar refers to figs 1-8 and lower scale bar to figs $9-17$. 
The magnitude of sea-level fluctuations cannot be constrained on the basis of the $N$. duwi assemblage, as the nominative species appears to be able to shift its depth distribution following a restoration of the benthic environment after widespread anoxia in the basin; however, based on the general benthic foraminiferal assemblage changes, the magnitude of shallowing and subsequent deepening across the LDE is estimated to be about $50 \mathrm{~m}$ maximum. A similar order of environmental changes is recorded in other Paleocene sections in the Nile Basin in Egypt. The event beds of the LDE are correlative with carbon isotope excursions in Zumaia, Spain, and in several open-ocean records from the Atlantic and Pacific and probably represent environmental changes associated with a Paleocene hyperthermal. Nannoflora and foraminifera record abundance shifts across the LDE, which are in certain aspects comparable to the PETM, but extinctions of benthic foraminifera do not occur; suggesting a lesser impact of the LDE compared to the PETM.

\section{Manuscript received 18 November 2010 Manuscript accepted 7 May 2011 \\ Scientific editing by Alan Lord}

\section{APPENDIX A: SPECIES LIST}

Several species are illustrated in Plate 1. For additional illustrations and references to taxonomical literature, see Speijer \& Schmitz (1998) and Ernst et al. (2006).

Alabamina midwayensis Brotzen, 1948

Alabamina cf. A. creta Finlay, 1940

Ammodiscus cretaceus (Reuss, 1845)

Angulogavelinella avnimelechi (Reiss, 1952)

Anomalinoides affinis (Hantken, 1875)

Anomalinoides midwayensis (Plummer, 1926)

Anomalinoides praeacutus (Vasilenko, 1950)

Anomalinoides rubiginosus (Cushman, 1926)

Anomalinoides susanaensis (Browning, 1959)

Bulimina farafraensis LeRoy, 1953

Bulimina midwayensis (Cushman \& Parker, 1936)

Bulimina quadrata Plummer, 1927

Bulimina strobila Marie, 1941

Bulimina thanatensis Cushman \& Parker, 1947

Cibicidoides alleni (Plummer, 1927)

Cibicidoides cf. C. hyphalus (Fisher, 1969)

Cibicidoides pseudoacutus (Nakkady, 1950)

Cibicidoides rigidus (Nakkady, 1959)

Cibicidoides succedens (Brotzen, 1948)

Coryphostoma cf. C. midwayensis (Cushman, 1936)

Eponides lunatus Brotzen, 1948

Gaudryina pyramidata Cushman, 1946

Gavelinella beccariiformis (White, 1928)

Globocassidulina subglobosa (Brady, 1881)

Gyroidinoides globosus (von Hagenow, 1842)

Gyroidinoides cf. G. tellburmaensis Futyan, 1976

Hansenisca girardanus (Reuss, 1851)

Loxostomoides applinae (Plummer, 1927)

Neoeponides duwi (Nakkady, 1950)

Nuttalides truempyi (Nuttall, 1930)

Oridorsalis plummerae (Cushman, 1948)

Osangularia plummerae Brotzen, 1940
Pullenia jarvisi Cushman, 1936

Pulsiphonina prima (Plummer, 1927)

Siphogenerinoides elegantus (Plummer, 1927)

Siphogenerinoides esnehensis (Nakkady, 1950)

Spiroplectinella dentata (Alth, 1850)

Spiroplectinella knebeli (LeRoy, 1953)

Stilostomella plummerae (Cushman, 1940)

Sporobulimina eocaena Bykova, 1959

Tappanina selmensis (Cushman, 1933)

Tritaxia midwayensis (Cushman, 1936)

Valvalabamina depressa (Alth, 1850)

Valvalabamina planulata (Cushman \& Renz, 1941)

Valvulineria? insueta (Cushman \& Bermudez, 1951)

\section{ACKNOWLEGEMENTS}

We are very grateful to the field assistants of South Valley University in Egypt for their help with collecting the samples. Special thanks go to Andriy Cheburkin and the University of Heidelberg for trace element analyses and the University of Erlangen for stable isotope analyses. We acknowledge discussions with Michael Joachimski (Erlangen University) on isotope data, and Bill Berggren and Dick Olsson (Rutgers University) on planktic foraminiferal taxonomy. Constructive reviews by Ellen Thomas and Laia Alegret are highly appreciated. This study was supported by grants from the Research Foundation Flanders (FWO - G.0527.05), the K.U.Leuven Research Fund, and the Herta and Hartmut Schmauser Stiftung from the University of Erlangen.

\section{REFERENCES}

Agnini, C., Fornaciari, E., Raffi, I., Rio, D., Röhl, U. \& Westerhold, T. 2007. High-resolution nannofossil biochronology of middle Paleocene to early Eocene at ODP Site 1262: Implications for calcareous nannoplankton evolution. Marine Micropaleontology, 64: 215-248.

Agnini, C., Macrì, P., Backman, J. et al. 2009. An early Eocene carbon cycle perturbation at $52.5 \mathrm{Ma}$ in the Southern Alps: Chronology and biotic response. Paleoceanography, 24, doi: 10.1029/2008PA001649.

Arenillas, I., Molina, E., Ortiz, S. \& Schmitz, B. 2008. Foraminiferal and stable isotopic event-stratigraphy across the Danian-Selandian transition at Zumaya (northern Spain): chronostratigraphic implications. Terra Nova; 20: 38-44.

Aubry, M-P. 1998. Early Paleogene calcareous nannoplankton evolution: A tale of climatic amelioration. In: Aubry, M.-P., Lucas, S.G. \& Berggren, W.A. (Eds), Late Paleocene-early Eocene climatic and biotic events in the marine and terrestrial records. Columbia University Press, New York, pp. 158-203.

Berger, W.H. \& Diester-Haass, L. 1988. Paleoproductivity; the benthic/ planktonic ratio in foraminifera as a productivity index. Marine Geology, 81: 15-25.

Berggren, W.A., Kent, D.V., Swisher, C.C. \& Aubry, M-P. 1995. A revised Paleogene Geochronology and Chronostratigraphy. In: Berggren, W.A. et al. (Eds), Geochronology, Time Scales and Global Stratigraphic Correlation. SEPM Special Publication, 54: 129-212.

Berggren, W.A. \& Pearson, P.N. 2005. A revised tropical to subtropical Paleogene planktonic foraminiferal zonation. Journal of Foraminiferal Research, 35: 279-314.

Bernaola, G., Baceta, J.I., Orue-Etxebarria, X., Alegret, L., Martín-Rubio, M., Arostegui, J. \& Dinarès-Turell, J. 2007. Evidence of an abrupt environmental disruption during the mid-Paleocene biotic event (Zumaia section, western Pyrenees). Geological Society of America Bulletin, 119: 785-795.

Bernaola, G., Martín-Rubio, M. \& Baceta, J.J. 2009. New high resolution calcareous nannofossil analysis across the Danian/Selandian transition at the Zumaia section: comparison with South Tethys and Danish sections. Geologica Acta, 7: 79-92. 
Blow, W.H. 1979. The Cainozoic Globigerinida: a Study of the Morphology, Taxonomy, Evolutionary Relationships and the Stratigraphical Distribution of some Globigerinida (mainly Globigerinacea), 1-3. E.J. Brill, Leiden, the Netherlands, 1413pp.

Bornemann, A., Schulte, P., Sprong, J., Steurbaut, E., Youssef, M. \& Speijer, R.P. 2009. Latest Danian carbon isotope anomaly and associated environmental change in the southern Tethys (Nile Basin, Egypt). Journal of the Geological Society, London, 166: 11351142.

Cachao, M. \& Moita, M.T. 2000. Coccolithus pelagicus, a productivity proxy related to moderate fronts off Western Iberia. Marine Micropaleontology, 39: 131-155.

Calvert, S.E. \& Pedersen, T.F. 1993. Geochemistry of recent oxic and anoxic marine sediments: Implications for the geological record. Marine Geology; 113: 67-88.

Cheburkin, A.K. \& Shotyk, W. 1996. An Energy-dispersive Miniprobe Multielement Analyzer (EMMA) for direct analysis of $\mathrm{Pb}$ and other trace elements in peats. Fresenius Journal of Analytical Chemistry, 354: 688-691.

Coccioni, R., Frontalini, F., Bancalà, G., Fornaciari, E., Jovane, L. \& Sprovieri, M. 2010. The Dan-C2 hyperthermal event at Gubbio (Italy): Global implications, environmental effects, and cause(s). Earth and Planetary Science Letters, 297: 298-305.

Corliss, B.H. \& Chen, C. 1988. Morphotype patterns of Norwegian Sea deep-sea benthic foraminifera and ecological implications. Geology; 16: 716-719.

Dinarès-Turell, J., Stoykova, K., Baceta, J.I., Ivanov, M. \& Pujalte, V. 2010. High-resolution intra- and interbasinal correlation of the Danian-Selandian transition (Early Paleocene): the Bjala section (Bulgaria) and the Selandian GSSP at Zumaia (Spain). Palaeogeography, Palaeoclimatology, Palaeoecology, 297: 511-533.

Dypvik, H. \& Harris, N.B. 2001. Geochemical facies analysis of fine-grained siliciclastics using $\mathrm{Th} / \mathrm{U}, \mathrm{Zr} / \mathrm{Rb}$ and $(\mathrm{Zr}+\mathrm{Rb}) / \mathrm{Sr}$ ratios. Chemical Geology, 181: 131-146.

Ernst, S.R., Guasti, E., Dupuis, C. \& Speijer, R.P. 2006. Environmental perturbation in the southern Tethys across the Paleocene/Eocene boundary (Dababiya, Egypt): Foraminiferal and clay mineral records. Marine Micropaleontology, 60: 89-111.

Geisen, M., Bollmann, J., Herrle, J., Mutterlose, J. \& Young, J. 1999. Calibration of the random settling technique for calculation of absolute abundances of calcareous nannofossil. Micropaleontology; 45: 437-442.

Grimsdale, T.F. \& Van Morkhoven, F.P.C.M. 1955. The ratio between pelagic and benthonic Foraminifera as a means of estimating depth of deposition of sedimentary rocks. Proceedings of the 4th World Petroleum Congress, Rome, 1: 473-491.

Guasti, E., Speijer, R., Brinkhuis, H., Smit, J. \& Steurbaut, E. 2006. Paleoenvironmental change at the Danian-Selandian transition in Tunisia: planktic foraminifera and organic-walled dinoflagellate cysts records. Marine Micropaleontology, 59: 210-229.

Hammer, Ø., Harper, D.A.T. \& Ryan, P.D. 2001. PAST: Paleontological Statistics Software Package for Education and Data Analysis. Palaeontologia Electronica, 4, http://palaeo-electronica.org/2001_1/ toc.htm.

Haq, B.U. \& Lohmann, G.P. 1976. Early Cenozoic calcareous nannoplankton biogeography of the Atlantic Ocean. Marine Micropaleontology, 1: 119-194.

Hendriks, F., Luger, P., Bowitz, J. \& Kallenbach, H. 1987. Evolution of depositional environments of SE-Egypt during the Cretaceous and lower Tertiary. Berliner Geowissenschaftliche Abhandlungen, Reihe A: Geologie und Paläontologie, 75: 49-82.

Hess, S., Kuhnt, W., Hill, S., Kaminski, M.A. \& De Leon, M. 2001. Monitoring the recolonization of the Mt Pinatubo 1991 ash layer by benthic foraminifera. Marine Micropaleontology, 43: 119-142.

Higgs, N.C., Thomson, J., Wilson, T.R.S. \& Croudace, I.W. 1994. Modification and complete removal of eastern Mediterranean sapropels by postdepositional oxidation. Geology, 22: 423-426.

Jiang, S. \& Wise, S.W. 2006. Surface-water chemistry and fertility variations in the tropical Atlantic across the Paleocene/Eocene Thermal Maximum as evidenced by calcareous nannofossils from ODP Leg 207, Hole 1259B. Revue de Micropaléontologie, 49: 227-244.
Jorissen, F.J., De Stigter, H.C. \& Widmark, J.G.V. 1995. A conceptual model explaining benthic foraminiferal microhabitats. In: Langer, M.R. (Ed.), FORAMS 1994. Marine Micropaleontology, 26: 3-15.

Knox, R.W.O., Aubry, M-P., Berggren, W.A., Dupuis, C., Ouda, K., Magioncalda, R. \& Soliman, M. 2003. The Qreiya section at Gebel Abu Had: Lithostratigraphy, clay mineralogy, geochemistry and biostratigraphy. Micropaleontology, 49: 93-104.

Koho, K.A., Kouwenhoven, T.J., de Stigter, H.C. \& van der Zwaan, G.J. 2007. Benthic foraminifera in the Nazaré Canyon, Portuguese continental margin: Sedimentary environments and disturbance. Marine Micropaleontology, 66: 27-51.

Lourens, L.J., Sluijs, A., Kroon, D. et al. 2005. Astronomical pacing of late Palaeocene to early Eocene global warming events. Nature, $\mathbf{4 3 5}$ : 1083-1087.

Luger, P. 1985. Stratigraphie der marinen Oberkreide und des Alttertiärs im südwestlichen Obernil-Becken (SW Ägypten) unter besonderer Berücksichtigung der Mikropaläontologie, Paläoekologie und Paläogeographie. Berliner Geowissenschaftliche Abhandlungen. Reihe A, Geologie und Paläontologie, 63: 1-151.

Luger, P. 1988. Maestrichtian to Paleocene facies evolution and Cretaceous/Tertiary boundary in middle and southern Egypt. Revista Española de Paleontologia, Numero extraordinario: 83-90.

Luterbacher, H.P., Ali, J.R., Brinkhuis, H. et al. 2004. The Paleogene period. In: Gradstein, F.M., Ogg, J.G. \& Smith, A.G. (Eds), A Geologic Time Scale 2004. Cambridge University Press, 610pp.

Marcantonio, F., Thomas, D.J., Woodard, S., McGee, D. \& Winckler, G. 2010. Extraterrestrial ${ }^{3} \mathrm{He}$ in Paleocene sediments from Shatsky Rise: Constraints on sedimentation rate variability. Earth and Planetary Science Letters, 287: 24-30.

Martini, E. 1971. Standard Tertiary and Quaternary calcareous nannofossil zonation. In: Farinacci, A. (Ed.), Proceedings of the 2nd Planktonic Conference, Rome, 1970. Tecnoscienza, Rome, 739-785.

Monechi, S., Angori, E. \& Speijer, R.P. 2000. Upper Paleocene biostratigraphy in the Mediterranean region: zonal markers, diachronism, and preservational problems. GFF, 122: 108-110.

Morford, J.L. \& Emerson, S. 1999. The geochemistry of redox sensitive trace metals in sediments. Geochimica et Cosmochimica Acta, 63: 1735-1750.

Müller, C. 1985, Late Miocene to recent Mediterranean biostratigraphy and paleoenvironments based on calcareous nannoplankton. In: Stanley, D.J. \& Wezel, F.C. (Eds) Geological evolution of the Mediterranean Basin. Springer-Verlag, New York, 471-485.

Mutterlose, J., Linnert, C. \& Norris, R. 2007. Calcareous nannofossils from the Paleocene-Eocene thermal maximum of the equatorial Atlantic (ODP Site 1260B): Evidence for tropical warming. Marine Micropaleontology, 65: 13-31.

Negri, A., Morigi, C. \& Giunta, S. 2003. Are productivity and stratification important to sapropel deposition? Microfossil evidence from late Pliocene insolation cycle 180 at Vrica, Calabria. Palaeogeography, Palaeoclimatology, Palaeoecology, 190: 243-255.

Nicolo, M.J., Dickens, G.R., Hollis, C.J. \& Zachos, J.C. 2007. Multiple early Eocene hyperthermals: Their sedimentary expression on the New Zealand continental margin and in the deep sea. Geology, 35: 699-702.

Nijenhuis, I.A., Bosch, H.J., Sinninghe Damste, J.S., Brumsack, H-J. \& de Lange, G.J. 1999. Organic matter and trace element rich sapropels and black shales: A geochemical comparison. Earth and Planetary Science Letters, 169: 277-290.

Nguyen, T.M.P., Petrizzo, M.R. \& Speijer, R.P. 2009. Experimental dissolution of a fossil foraminiferal assemblage (Paleocene-Eocene Thermal Maximum, Dababiya, Egypt): Implications for paleoenvironmental reconstructions. Marine Micropaleontology, 73: 241-258.

Okada, H. \& Honjo, S. 1973. The distribution of oceanic coccolithophorids in the Pacific. Deep-Sea Research, 20: 55-374.

Okada, H. \& McIntyre, A. 1979. Seasonal distribution of modern coccolithophores in the western North Atlantic Ocean. Marine Biology, 54: 319-328.

Olsson, R.K., Hemleben, C., Berggren, W.A. \& Huber, B.T. (Eds) 1999. Atlas of Palaeocene planktonic foraminifera. Smithsonian Contributions to Paleobiology, 85: 1-254. 
Perch-Nielsen, K. 1985. Cenozoic calcareous nannofossils. In: Bolli, H.M. (Ed.), Plankton Stratigraphy. Cambridge University Press, Cambridge, 427-554.

Petrizzo, M.R. 2005. An early late Paleocene event on Shatsky Rise, northwest Pacific Ocean (ODP Leg 198): Evidence from planktonic foraminiferal assemblages. In: Bralower, T.J., Premoli Silva, I. \& Malone, M.J. (Eds), An early late Paleocene event on Shatsky Rise, northwest Pacific Ocean (ODP Leg 198): Evidence from planktonic foraminiferal assemblages. Proceedings of the Ocean Drilling Project, Scientific Results, 198: 1-29.

Pflum, C. \& Frerichs, W. 1976. Gulf of Mexico deep water foraminifers Cushman Foundation for Foraminiferal Research, Special Publication, 14: $1-125$.

Premoli Silva, I., Rettori, R. \& Verga, D. 2003. Practical manual of Paleocene and Eocene planktic foraminifera. Course handbook, University of Perugia, Perugia, 152pp.

Quillévéré, F., Aubry, M-P., Norris, R.D. \& Berggren, W.A. 2002. Paleocene oceanography of the eastern subtropical Indian Ocean: an integrated magnetostratigraphic and stable isotope study of ODP Hole 761B (Wombat Plateau). Palaeogeography, Palaeoclimatology, Palaeoecology, 184: 371-405.

Quillévéré, F., Norris, R.D., Kroon, D. \& Wilson, P.A. 2008. Transient ocean warming and shifts in carbon reservoirs during the early Danian. Earth and Planetary Science Letters, 265: 600-615.

Raffi, I. \& Rio, D. 1981. Coccolithus pelagicus (Wallich): a paleotemperature indicator in the late Pliocene Mediterranean deep sea record. In: Wezel, F.C. (Ed.), Sedimentary Basins of Mediterranean Margins. C.N.R. Italian Project of Oceanography, Bologna (Tecnoprint), 187-190.

Said, R. 1962. The geology of Egypt. Elsevier, Amsterdam, 377pp.

Schmitz, B., Charisi, S.D., Thompson, E.I. \& Speijer, R.P. 1997. Barium, $\mathrm{SiO}_{2}$ (excess), and $\mathrm{P}_{2} \mathrm{O}_{5}$ as proxies of biological productivity in the Middle East during the Paleocene and the latest Paleocene benthic extinction event. Terra Nova, 9: 95-99.

Schmitz, B., Schmitz, Alegret, L. et al. 2008. Proposed Global Stratotype Sections and Points for the bases of the Selandian and Thanetian stages (Paleocene Series). Report of the Paleocene Working Group for the International Subcommission on Paleogene Stratigraphy, http:// www.earth-prints.org/handle/2122/3795.

Schmitz, B., Speijer, R.P. \& Aubry, M-P. 1996. Latest Palaeocene benthic extinction event on the southern Tethyan shelf (Egypt): Foraminiferal stable isotopic $\left(\delta^{13} \mathrm{C}, \delta^{18} \mathrm{O}\right)$ records. Geology, 24: 347-350.

Schnack, K. 2000. Biostratigraphie und fazielle Entwicklung in der Oberkreide und im Alttertiär im Bereich der Kharga Schwelle, Westliche Wüste, südwest Ägypten. Berichte aus dem Fachbereich Geowissenschaften der Universität Bremen, 151: 1-142.

Schulte, P. \& Speijer, R.P. 2009. Late Maastrichtian-Early Paleocene sea level and climate changes in the Antioch Church Core (Alabama, Gulf of Mexico margin, USA): A multi-proxy approach. Geologica Acta, 7: 11-34.

Shannon, C.E. \& Weaver, W. 1949. The Mathematical Theory of Communication. University of Illinois Press, Urbana, 117pp.

Soliman, M.F. \& Obaidalla, N.A. 2010. Danian-Selandian transition at Gabal el-Qreiya section, Nile Valley (Egypt): lithostratigraphy, biostratigraphy, mineralogy and geochemistry. Neues Jahbuch für Geologie und Paläontologie, 258: 1-30.

Speijer, R.P. 2000. The late Paleocene event and a potential precursor compared: first results from Egypt. GFF, 122: 150-151.

Speijer, R.P. 2003a. Danian-Selandian sea-level change and biotic excursion on the southern Tethyan margin. In: Wing, S.L., Gingerich, P.D., Schmitz, B. \& Thomas, E. (Eds), Causes and consequences of globally warm climates in the Early Paleogene. Geological Society of America Special Paper, 369: 275-290.

Speijer, R.P. 2003b. Systematics and paleoecology of the foraminifer Neoeponides duwi (Nakkady) from the Paleocene of Egypt. Micropaleontology, 49: 146-150.

Speijer, R.P. \& Schmitz, B. 1998. A benthic foraminiferal record of Paleocene sea level and trophic/redox conditions at Gebel Aweina, Egypt. Palaeogeography, Palaeoclimatology, Palaeoecology, 137: 79-101.

Speijer, R.P. \& Wagner, T. 2002. Sea-level changes and black shales associated with the late Paleocene thermal maximum (LPTM); organic-geochemical and micropaleontologic evidence from the southern Tethyan margin (Egypt-Israel). In: Koeberl, C. \& MacLeod, K.G. (Eds), Catastrophic Events and Mass Extinctions: Impacts and Beyond. Geological Society of America Special Paper, 356: 533-549.

Sprong, J., Speijer, R.P. \& Steurbaut, E. 2009. Biostratigraphy of the Danian/Selandian transition in the southern Tethys. Special reference to the Lowest Occurrence of planktic foraminifera Igorina albeari. Geologica Acta, 7: 63-77.

Stap, L., Sluijs, A., Thomas, E. \& Lourens, L. 2009. Patterns and magnitude of deep sea carbonate dissolution during Eocene Thermal Maximum 2 and H2, Walvis Ridge, southeastern Atlantic Ocean. Paleoceanography, 24, PA1211, 13 pp., doi: 10.1029/2008PA001655.

Stassen, P., Dupuis, C., Morsi, A.M., Steurbaut, E. \& Speijer, R.P. 2009. Reconstruction of a latest Paleocene shallow-marine eutrophic paleoenvironment at Sidi Nasseur (Central Tunisia) based on foraminifera, ostracoda, calcareous nannofossils and stable isotopes (813C, 818O). Geologica Acta, 7: doi: 10.1344/105.000000273.

Steurbaut, E., Dupuis, C., Arenillas, I., Molina, E. \& Matmati, M.F. 2000. The Kalaat Senan section in central Tunisia: a potential reference section for the Danian/Selandian boundary. GFF, 122: 158-160.

Steurbaut, E. \& Sztrákos, K. 2008. Danian/Selandian boundary criteria and North Sea Basin-Tethys correlations based on calcareous nannofossil and foraminiferal trends in SW France. Marine Micropaleontology, 67: 1-29.

Thomas, E. 1998. The biogeography of the late Paleocene benthic foraminiferal extinction, In: Aubry, M-P., Lucas, S. \& Berggren, W.A. (Eds), Late Paleocene-early Eocene Biotic and Climatic Events in the Marine and Terrestrial Records. Columbia University Press, 214-243.

Thomas, E. \& Zachos, J.C. 2000. Was the late Paleocene thermal maximum a unique event? GFF, 122: 169-170.

Thomson, J., Higgs, N.C., Wilson, T.R.S., Croudace, G.J., de Lange, G.J. \& van Santvoort, P.J.M. 1995. Redistribution and geochemical behaviour of redox-sensitive elements around $\mathrm{S} 1$, the most recent eastern Mediterranean sapropel. Geochimica et Cosmochimica Acta, 59: $3487-3501$.

Toumarkine, M. \& Luterbacher, H.P. 1985. Paleocene and Eocene planktic foraminifera. In: Bolli, H.M, Saunders, J.B. \& Perch-Nielsen, K. (Eds), Plankton Stratigraphy. Cambridge University Press, Cambridge, 87-154.

Tribovillard, N., Algeo, T.J., Lyons, T. \& Riboulleau, A. 2006. Trace metals as paleoredox and paleoproductivity proxies: An update. Chemical Geology, 232: 12-32.

Van der Zwaan, G.J., Jorissen, F.J. \& De Stigter, H.C. 1990. The depth dependency of planktonic/benthic foraminiferal ratios: Constraints and applications. Marine Geology, 95: 1-16.

Van Itterbeeck, J., Sprong, J., Dupuis, C., Speijer, R.P. \& Steurbaut, E. 2007. Danian/Selandian boundary stratigraphy, paleoenvironment and Ostracoda from Sidi Nasseur, Tunisia. Marine Micropaleontology, 62: 211-234.

Van Morkhoven, F.P.C.M., Berggren, W.A. \& Edwards, A.S. 1986. Cenozoic Cosmopolitan Deep-Water Benthic Foraminifera. Elf Aquitaine, Pau, 421pp.

Varol, O. 1989. Paleocene calcareous nannofossil biostratigraphy. In: Van Heck, S.E. (Ed.), Nannofossils and their applications. Ellis Horwood Ltd, Chichester, 267-310.

Westerhold, T., Röhl, U., Donner, B., McCarren, H. \& Zachos, J. 2011. A complete high-resolution Paleocene benthic stable isotope record for the Central Pacific (ODP site 1209). Paleoceanography, doi: 10.1029/2010PA002092.

Westerhold, T., Röhl, U., Raffi, I. et al. 2008. Astronomical calibration of the Paleocene time. Palaeogeography, Palaeoclimatology, Palaeoecology, 257: 377-403.

Widmark, J.G.V. \& Speijer, R.P. 1997. Benthic foraminiferal ecomarker species of the terminal Cretaceous (late Maastrichtian) deep-sea Tethys. Marine Micropaleontology, 31: 135-155.

Youssef, M.A. 2009. High resolution calcareous nannofossil biostratigraphy and paleoecology across the Latest Danian Event (LDE) in central Eastern Desert, Egypt. Marine Micropaleontology, 72: 111-128. 